\title{
Investigating Nineteenth-Century Transcriptions through History of Opera and Music Publishing: Mauro Giuliani's Sources for Two Themes in Le Rossiniane No. 2, Op. 120, and No. 3, Op. 121
}

\author{
Francesco Teopini Terzetti Casagrande \\ Hong Kong Baptist University \\ Baptist University Rd, Kowloon Tong \\ Hong Kong SAR \\ e-mail: chitarristo@gmail.com
}

DOI: https://doi.org/10.37134/mjm.vol8.2.2019

Published online: 1 August 2019

Teopini Terzetti Casagrande, F. (2019). Investigating Nineteenth-Century Transcriptions through History of Opera and Music Publishing: Mauro Giuliani's Sources for Two Themes in Le Rossiniane No. 2, Op. 120, and No. 3, Op. 121. Malaysian Journal of Music, 8, 19-51. https://doi.org/10.37134/mjm.vol8.2.2019

\begin{abstract}
In a letter to the publisher Ricordi dated 6 February 1821, the Italian guitarist and composer Mauro Giuliani wrote that, after getting acquainted with Gioachino Rossini in Rome, Rossini lent him many autographs of his operas so that the guitarist could transcribe whatever he liked from them. From this loan were born Le Rossiniane Opp. 119-124, six potpourris for solo guitar which are considered Giuliani's greatest musical accomplishment. Although it is likely that most of the sources of Le Rossiniane were Rossini's originals, there is also epistolary evidence that Giuliani also transcribed themes from scores provided to him by his publishers. This fact is the point of departure from which this article explores the possible sources for two opera themes transcribed in Le Rossiniane No. 2, Op. 120, and No. 3, Op. 121. The data presented here, coming from opera and music publishing history, conveys that such themes may have been transcribed from two specific vocal scores issued by Viennabased publishing houses - 'Cappi and Diabelli' and 'Artaria'. Additionally, the exploration of the context of the opera themes at issue has also brought to light some interesting unpublished facts.
\end{abstract}

Keywords: arrangements, Giuliani, guitar, Le Rossiniane, opera, Rossini, transcriptions 


\section{Introduction}

During the last few decades, the art of music transcription ${ }^{1}$ has been receiving the kind of interest from performers, scholars, and audiences, which throughout most of the twentieth century was only aimed at original repertoire. As a matter of fact, classical music lovers of that period manifested a rather scarce interest towards transcriptions, due to the bad reputation that these had among musicians, critics, and (less often) audiences. Urrows (2008) states:

During most of the twentieth century, the so-called 'Age of Authenticity' [sic.], such works were dismissed as 'derangements', vandali[s]ations of the 'authentic' forms of works, generally as manifestations of appallingly bad taste ... Behind this attitude lurk[ed] the evangelical spirit of twentieth-century musical scholarship, for which [transcription] was a kind of crime against the very nature of musical art. (pp. 136-137)

Although the above passage seems to describe a typical twentieth-century opinion on transcriptions, this did not completely originate at that time. Such a strong belief was the result of a philosophical inheritance coming from the nineteenth century, more specifically from the (moralistic) Romantic views on arts' originality and inimitability. According to Samson (2001), during Romanticism transcriptions:

[S]tood in a somewhat uneasy relationship to the prevailing Romantic ideology. Romanticism, after all, privileged the singular and the inimitable, qualities that seem on the face of it at some remove from the ... transcription of another's work. Thus the Romantic premium on originality brought into sharp focus ethical as well as ontological questions which had seemed less pressing (though they were indeed raised) during earlier periods. (p. 269)

In spite of this, for the whole nineteenth century composers still found transcriptions to be crucial for the promotion and spreading of their music. MillerKay (2018) affirms that generally these composers - among whom we find personalities such as Ludwig van Beethoven (1770-1827) and Johannes Brahms (1833-1897) - were aware of the fact that transcriptions "were the primary form in which their music would be disseminated" (p. 196).

One nineteenth-century musician who, more than any of his contemporaries, enjoyed how functional transcriptions were for the dissemination of his music across all of Europe was the Pesaro-born composer Gioachino Rossini (1792-1868). Due to his status as the most celebrated operista of the first decades of the nineteenth century, in those particular times transcriptions of Rossini's music were published frequently. For instance, Bianca Maria Antolini (2001) mentions that in 1820 s Italy almost every publisher of the country issued excerpts from his operas, transcribed either for voice and piano or for various other types of instrumental ensemble (p. 99).

Among the many types of transcriptions circulating during the first half of the nineteenth century, one in particular became especially successful among 
European audiences. This was the potpourri, a kind of instrumental fantasia (Czerny, 1848, 82) ${ }^{2}$ which exploited "[the] desire of the public to possess the beautiful melodies of favorite [o]peras, tastefully and connectedly strung together" (ibid., p. 87). In this regard, Carl Czerny (1791-1857) explains that audiences were always pleased to listen to well-structured fantasias featuring popular opera themes:

The public in general, experiences great delight on finding in a composition some pleasing melody with which is already familiar, and which it has previously heard with rapture at the [o]pera: for most melodies acquire their popularity by the fine performance of a human voice and the charm of theatrical effect. Now, when such melodies are introduced in a spirited and brilliant manner in a [f]antasia [italic added], and there developed or varied, both the composer and the practiced player can ensure great success. (ibid., p. 86)

It is not hazardous to imagine that Rossini knew as well as Czerny that transcriptions, and among those fantasias, were such a commercial success for both the transcriber and the 'transcribed'. Maybe it was this particular awareness that, during a sojourn in Rome between 1820 and $1821,{ }^{3}$ prompted Rossini to lend many of his original opera scores to the Italian guitar virtuoso and composer Mauro Giuliani (1781-1829), so that the guitarist could transcribe whatever he wished from them. ${ }^{4}$

Giuliani, a master of transcription, ${ }^{5}$ made the most out of his chance of having Rossini's autographs on loan by composing Le Rossiniane Opp. 119-124, his most famous works to date. Regarded as Giuliani's chef d'oeuvres, Le Rossiniane are a series of six potpourris for guitar composed during his stay in Rome and Naples between 1820 and 1829 (Heck, 2013, chap. 4.), where he moved after a 13 year-long residence in Vienna (ibid., chap. 3). Written as an homage to Rossini, they feature transcriptions of themes coming from 16 operas by the composer from Pesaro, ranging from the 1812 melodramma giocoso called La Pietra del Paragone to the 1826 tragédie lyrique titled Le Siège de Corinthe (Castelvecchi, 1986, pp. 5268).

Investigating Giuliani's sources for two themes in Le Rossiniane No. 2, Op. 120, and No. 3, Op. 121

This study was born from my pondering on whether or not Giuliani's claim that he borrowed many autographs from Rossini was a bit exaggerated, in order to sell his works to potential publishers. ${ }^{6}$ More precisely, for a long time I wondered how many (and what type of) other sources Giuliani may have ever utilised for his opera themes' transcriptions in Le Rossiniane besides Rossini's originals.

According to Marco Riboni (2011), it is highly probable that among the originals that Giuliani obtained from Rossini there were many of the themes that he used for his works (p. 437). However, Thomas Heck (2013) points out that Giuliani was also accustomed to transcribe music from scores provided to him by his publishers, evidence being a letter that Giuliani wrote to Domenico Artaria (17651823) complaining about the two publishers and business partners Pietro Cappi (ca. 
1790-1830) and Anton Diabelli (1781-1858), ${ }^{7}$ in which he reports the following words that he claimed to be written by them: "Here are some 'favorite themes' so that you can write us variations on them" (chap. 4.3.1).

Heck's evidence was for me the basis upon which I came up with some hypotheses about the sources for two specific opera themes that Giuliani transcribed for two of his Le Rossiniane. In point of fact my research, based on records about history of early nineteenth-century opera and music publishing which I gathered during the past few years, suggests that these sources are identifiable as two specific vocal scores by Vienna-based publishers Cappi and Diabelli, and Artaria. The themes at issue come from two cabalette: ${ }^{8}$ these are 'Nume, perdonami se in tale istante' (hereinafter referred to as 'Nume, perdonami') from the opera I Baccanali di Roma (1816) by Italian composer Pietro Generali (1773-1832), which Giuliani transcribed in both his Le Rossiniane No. 2 Op. 120 (hereinafter referred to as either Rossiniana No. 2, or simply Op. 120) as well as in his earlier Variations on 'Nume perdonami' Op. 102 (hereinafter referred to as either Variations Op. 102, or simply Op. 102), ${ }^{9}$ and 'Sorte, secondami!' from Rossini's opera Zelmira (1822), transcribed by the Italian guitarist in Le Rossiniane No. 3, Op. 121 (hereinafter referred to as either Rossiniana No. 3, or simply Op. 121).

Additionally, this study also wishes to further clarify why Giuliani chose to feature Generali's 'Nume, perdonami' in Op. 120, since the latter is (supposed to be) a work composed as a tribute to Rossini. Stefano Castelvecchi (1986) proposes a few hypotheses; among those, one in particular suggests that Giuliani may have quoted Generali's theme with the intent of hinting at the fact that Rossini plagiarised it as the cabaletta 'Arditi all'ire' present in his 1817 opera Armida (pp. 47-48). Here will be brought some extra evidences which, adding to Castelvecchi's, tell that his intuition may not have been that far from the truth.

\section{Rossiniana No. 2: 'Nume, perdonami' from I Baccanali di Roma}

According to Alberto Galazzo's Tra i Barbassori e gli Azzimati: Pietro Mercandetti Generali (2009) - a remarkable two-volume work on Pietro Generali's life and works - I Baccanali di Roma was Generali's most successful opera, staged with great success both all over Italy as well as overseas between 1816 and 1832 (pp. 7980). The opera achieved this sort of success after Generali revised it for its second staging which happened in Trieste in June 1816; as a matter of fact, the opera was not well received in its original version titled I Baccanti di Roma (ibid.). According to issue no. 26 of the Venetian newspaper Il Nuovo Postiglione, I Baccanti di Roma was premiered at the 'Teatro La Fenice' on 14 February $1816 .{ }^{10}$ The announcement, placed under the heading 'Spettacoli d'oggi [today's shows]', says:

"[L]a Fenice Theater. Performance of I Baccanti di Roma. [d]rama by [M]r. Gaetano Rossi, [m]usic by [M]r. Maestro Generali, with ballet: Aresping $e$ Lindane, composed by [M]r. Panzieri" (Figure 1). ${ }^{11}$ 
Here follow the names of each main singing member of the cast for the opera (and their respective roles), as listed by the libretto printed for the event (Generali and Rossi, 1816, p. 4): ${ }^{12}$

- Mr. Giovanni Battista Binaghi (SP. Postumo Albinio);

- Mr. Giovanni David (Sempronio);

- Mr. Francesco Desirò (Minio Cerinio);

- Mr. Giovanni Sebastiani (Publio Ebuzio);

- Ms. Elena Harlas (Fecenia), singer in the service of Maximilian I Joseph, King of Bavaria (1756-1825);

- Ms. Marietta Castiglioni (Ippia);

- Mr. Giovanni Cengia (Lentulo; Augure Sommo).

Figure 1. Announcement of the (first) performance of I Baccanti di Roma. (Il Nuovo Postiglione, 14 February 1816, p. 4.)

Issue No. 27 of the same newspaper, dated 16 February 1816, features an extensive review of the premiere of I Baccanti di Roma under the heading 'Teatri [Theaters]' (pp. 3-4). Among the interesting facts reported by the reviewer, there are two in particular which seem most relevant.

Firstly, the opera had to be suspended because of a sudden illness on stage of the prima donna Elena Harlas - ascribed by the reviewer to the many long, incessant rehearsals taking place before the premiere due to a delay in the delivery of the music - which forced her to suddenly leave after the end of one of her arias (Figure 2).

Secondly, among the most applauded musical moments in Generali's opera we find the 'cavatina di sortita [in] the first act [sung by] Mr. Sebastiani' (Figure 3). The cavatina di sortita described in the review is the cavatina ${ }^{13}$ in Act 1 Scene 3 titled 'Non temete: i sommi Dei ... Nume, perdonami' (Generali, 181?, pp. 114134), ${ }^{14}$ i.e. the entrance aria of Publio Ebuzio (castrato) - character which hereinafter will be referred to as simply Ebuzio. The cabaletta 'Nume, perdonami' coming from this cavatina was among the themes from the opera which became instantly popular among audiences due to its melodic beauty (Galazzo, 2009a, 80). Galazzo hypothesises that this could have been the reason why Giuliani decided to use Generali's theme for his Variations Op. 102 as well as in his Rossiniana No. 2, perhaps after attending one of the performances of Die Bachanten - i.e. the German language version of Generali's opera - held in Germany and Austria during the 1810s (ibid.). 


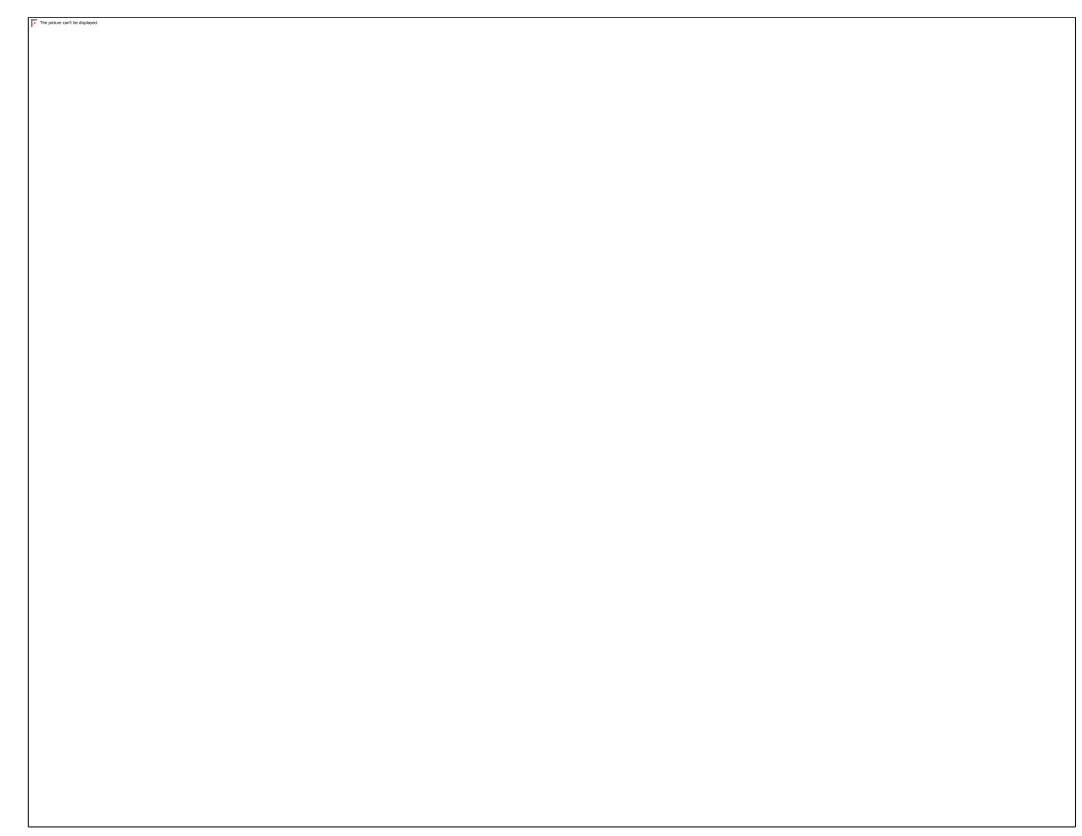

Figure 2. Review of the premiere of I Baccanti di Roma: first excerpt. (Il Nuovo Postiglione, No. 27 , p. 4. $)^{15}$

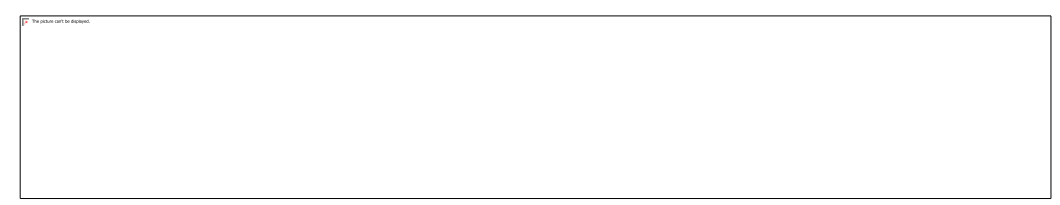

Figure 3. Review of the premiere of I Baccanti di Roma: second excerpt. (Il Nuovo Postiglione, No. 27, p. 4. $)^{16}$

Giuliani's Variations Op. 102, originally titled as Introduzione e variazioni sopra la cavatina favorita 'Nume perdonami, se in tale istante' nei Baccanali di Roma del sig. Generali (Introduction and variations on the favorite cavatina 'Nume perdonami, se in tale istante' in I Baccanali di Roma of [M]r. Generali), was published in 1819 (Giuliani, 1819; Weidmann, 1983, 29) for the Cappi and Diabelli's series Euterpe, and advertised in the Wiener Zeitung on 13 July of the same year (ibid.). These solo variations were later arranged as a quintet for guitar and string quartet and published in 1820 for their series Philomele für die Gitarre (ibid., 52). Conversely, Giuliani's Rossiniana No. 2 was published by Artaria in 1822 (Giuliani, 1819; Heck, 2013, 'Works with opus number'), and publicised in the Wiener Zeitung on 5 November of the same year (Giuliani, 2002, 'Preface: Publication'). Both Giuliani's transcriptions of the theme in Opp. 102 and 120 feature the tempo marking Allegretto innocente (Figure 4 and 5). 


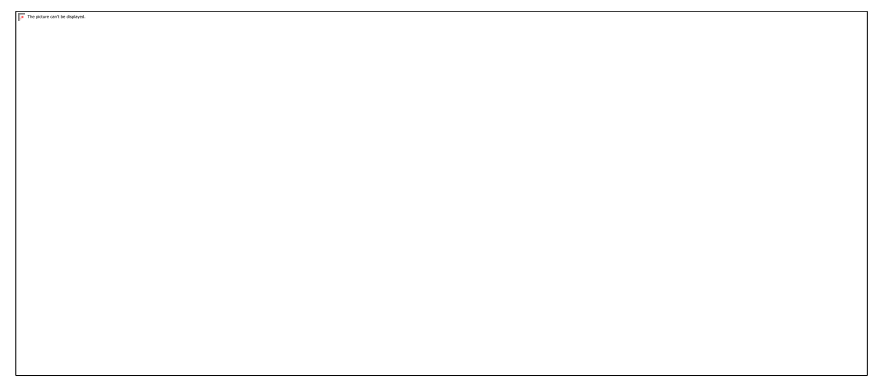

Figure 4. Variations Op. 102: tempo marking (green ellipse) featured in the theme of 'Nume, perdonami'. (Giuliani, 1819, p. 5.)

Figure 5. Rossiniana No. 2: tempo marking (green ellipse) featured in the theme of 'Nume, perdonami'. (Giuliani, 1822, p. 5.)

Both of them feature a theme in two-part song form; however, the version of 'Nume, perdonami' in Op. 120 is more elaborate and dynamic than the one in Op. 102, especially in its second part. Further, the version in Op. 102 concludes with a coda not to be found in Op. 120 (see Figure 6 and 7).

With regard to the tempo marking utilised by Giuliani, the Italian term innocente is not retrievable in the actual theme composed by Generali. Apparently, the tempo marking of the aria was a more ordinary Allegretto. This claim is based on the following evidences:

- The tempo marking on the scanned manuscript from the digital archive of the National Library of Spain in Madrid (Figure 8);

- The tempo marking on the manuscript from the British Library in London (Figure 9) - according to Amelie Roper (personal communication, March 27,2017 ), this particular manuscript is thought to be a copy prepared for the performance held in Trieste in June 1816;

- The tempo marking found in the 1817 manuscript of Die Bachanten available at the Bavarian State Library in Munich (Galazzo, 2009b, 196);

- The tempo marking featured in an 1820 manuscript of Die Bachanten, property of the Austrian National Library, as communicated to me by Andrea Harrandt (personal communication, May 28, 2018). 


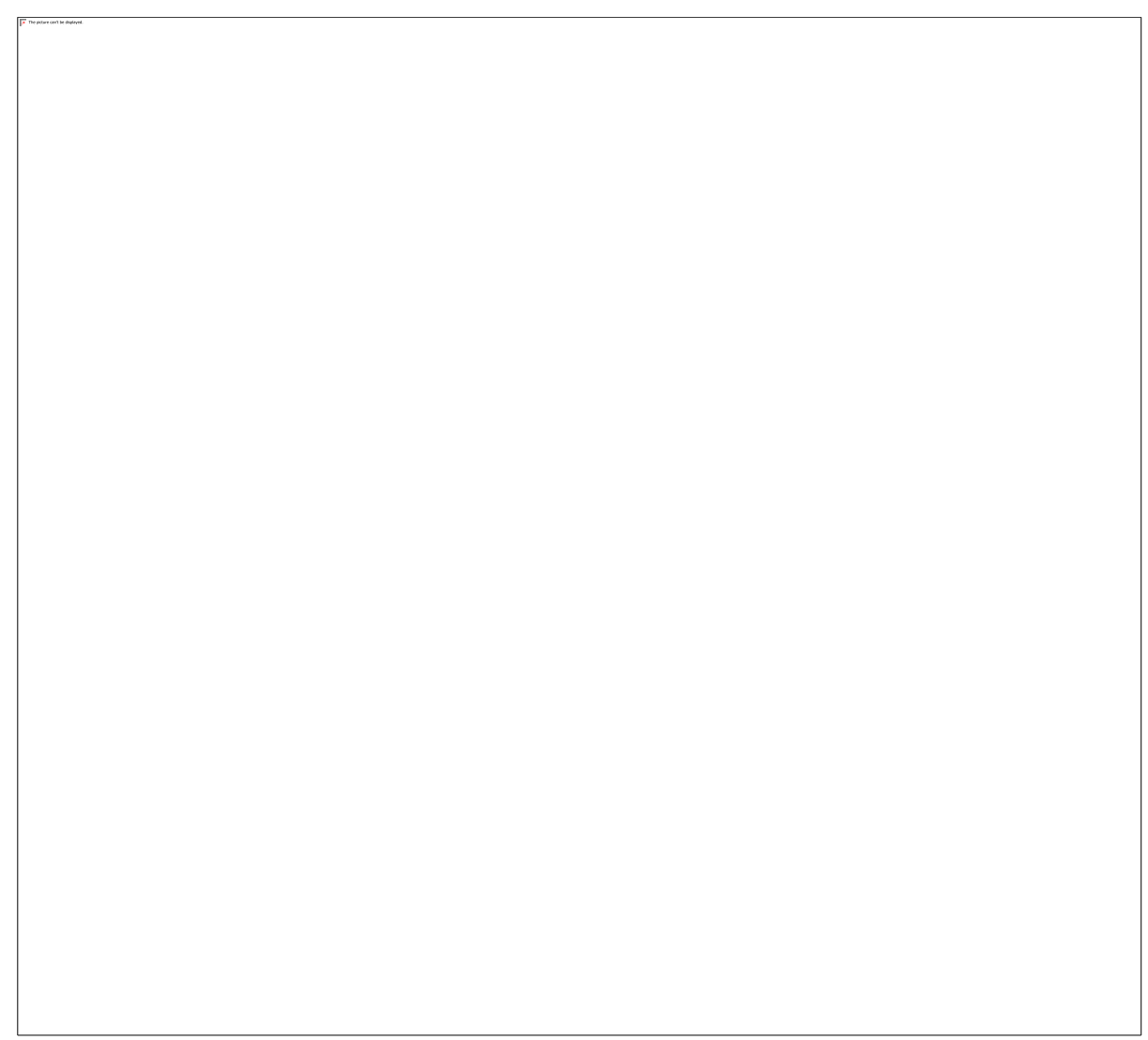

Figure 6. Variations Op. 102: second part of the theme of 'Nume, perdonami' - the coda of the theme is bordered in red. (Giuliani, 1819, p. 6.)

Figure 7. Rossiniana No. 2: Second part of the theme of 'Nume, perdonami'. (Giuliani, 1822, p. 5.) 


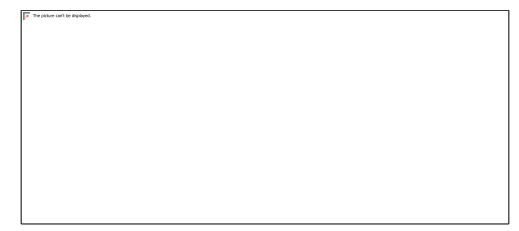

Figure 8. Tempo marking Allegretto (here spelled as All ${ }^{t t o}$ ) on the manuscript of I Baccanali di Roma owned by the National Library of Spain in Madrid. (Generali, 181?, p. 121.)

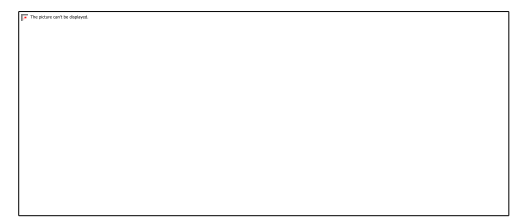

Figure 9. Tempo marking Allegretto (here spelled as All ${ }^{\text {tto }}$ ) on the manuscript of I Baccanali di Roma owned by the British Library in London. (Generali, 1816, p. 95r.)

When it comes to the differences between the themes in Opp. 102 and 120, a comparison between the transcriptions by Giuliani and the manuscript from London shows that the theme in Op. 120 is more authentic to the opera's original. This is especially true in the case of Op. 120's melodic passage in semiquavers on the first three measures of the second part of the theme: it looks and sounds almost identical to the melody assigned by Generali to Ebuzio, a part from the beginning rhythm of dotted semiquavers and demisemiquavers in the first measure (Figure 10). This suggests that Giuliani may have decided to overall simplify the second part of the theme in Op. 102, in order to make the subsequent variations of this piece sound more gradual in terms of virtuosity.

Figure 10. Singer's melody in the second part of the theme of 'Nume, perdonami' - the first measure is bordered in red. (Generali, 1816, 95v-97v.) 
After the above description, there is a question which still seems to need an answer: since originally the aria 'Nume, perdonami' bears the tempo marking Allegretto, was there any source of Generali's I Baccanali di Roma where this aria featured the tempo marking Allegretto innocente which could have been available to Giuliani at the time he wrote Opp. 102 and 120? If yes, is there any chance that Giuliani may have transcribed this aria from such a source?

In his study on all six Le Rossiniane, Castelvecchi reproduces the first measures of the first part of the theme of 'Nume, perdonami', as found in Cappi and Diabelli's vocal score of Generali's cavatina: here the cabaletta bears the tempo marking Allegretto innocente (1986, p. 49). By looking at the original publication of Cappi and Diabelli, it can be confirmed that the tempo marking is indeed the one reported by Castelvecchi (Figure 11).

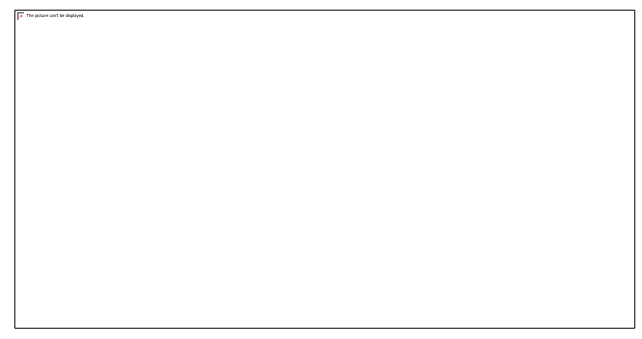

Figure 11. Tempo marking Allegretto innocente (green ellipse) in 'Nume, perdonami', as found in Cappi and Diabelli's vocal score. (Generali, 1820, p. 4.)

One may be prone to think that the tempo marking used by both Giuliani, and Cappi and Diabelli may be considered as evidence that Giuliani's main source for both Opp. 102 and 120 was this specific vocal score, even daring to speculate that maybe the publishers themselves provided it to him. However, there is a problem of anachronism when it comes to the year of publication of Op. 102. In fact, Cappi and Diabelli's version of 'Nume, perdonami' was published in 1820 as Vol. 41 of the series Philomele für Pianoforte (Weinmann, 1983, p. 50), ${ }^{17}$ the year of publication seems to fit with the Viennese premiere of Generali's opera, which took place at the Theater an der Wien on 12 June 1820 (Allgemeine musikalische Zeitung, 17 June 1820 , p. 388), ${ }^{18}$ and was later reviewed by the Wiener allgemeine Theaterzeitung und Unterhaltungsblatt (29 June 1820, p. 311). Therefore, it is unlikely that Giuliani may have had this particular score as the source for his Op. 102; nonetheless, so far the preceding data points to the fact that Giuliani may have used Cappi and Diabelli's vocal score for his Op. 120.

Cappi and Diabelli's vocal score shows that the melody in the first four measures of the second part of the theme is written almost exactly as the one in the original, with its first measure containing a rhythm of dotted semiquavers and demisemiquavers (Figure 12). Giuliani's same melodic segment in the Rossiniana No. 2 looks almost the same as Cappi and Diabelli's, a part from Giuliani's use of only semiquavers in its first measure. However, there is a score of Generali's whole opera appearing to be the only one published before 1820 which, despite featuring 
the tempo marking Allegretto and including a second part of Generali's theme not as authentic to the original as both Cappi and Diabelli's score and Giuliani's Op. 120, on that particular measure uses the exact rhythm found on the melody of Op. 120. The publication at issue is the vocal score of the German version of Generali's opera, i.e. Die Bachanten, published by Simrock (Figure 13) between Easter 1818 and Easter 1819 (Whistling, 1819, p. 63). ${ }^{19}$ The period of publication of Simrock's vocal score is temporally consistent with Giuliani's year of publication of Op. 102; further, it seems to go hand in hand with the German premieres of Die Bachanten held in Bonn and Cologne in 1818 (Galazzo, 2009b, p. 371), i.e. the cities where Nicolaus Simrock (1751-1832) and his son, Peter Joseph Simrock (1792-1868), respectively founded the publishing house - i.e. Berlin - and opened a branch - i.e. Cologne (Clive, 2001, pp. 337-338).

Figure 12. Second part of the melody of 'Nume, perdonami' in Cappi and Diabelli's vocal score - the first measure is bordered in red. (Generali, 1820, pp. 4-5.)

Figure 13. First page of 'Nume, perdonami' as featured in the vocal score of Die Bachanten published by Simrock, containing the tempo marking Allegretto (green ellipse). The first measure in the melody of the second part of the theme (bordered in red) features the same rhythm also found in Op. 120. (Generali, ca. 1818, p. 39.) 
All the data provided previously leads to the following hypotheses:

Firstly, Giuliani may have owned a copy of the vocal score published by Simrock, which he may have used for his transcription of the theme for his Variations Op. 102 (i.e. the least authentic to Generali's original theme). It is safe to assume that later he used the Cappi and Diabelli score for Op. 120, in order to render the theme closer to Generali's original - it is also rather interesting to see that conceivably Giuliani exploited a score issued by Cappi and Diabelli for a score then published by Artaria. However it can be supposed that the voice part's highly idiomatic dotted rhythm found in the original aria, which Giuliani transcribed in the first measure of the second part of the theme of Op. 120, may have been exemplified by him either on his own initiative or by drawing his 'inspiration' from Simrock's score. ${ }^{20}$

Secondly, it is possible that the adjective innocente (meaning 'innocent') was added by Giuliani himself in Op. 102 to signal the mood of the cabaletta in place of the lyrics - which, of course, cannot be performed in a solo instrumental piece. According to the lyrics of Generali's whole cavatina (Table 1), Ebuzio admits to his fellow Bacchants that he fell in love with Fecenia, i.e. the female protagonist of the opera, during his initiation rite to the cult of Bacchus - however, he does not mention her name to his fellows. Ebuzio asks for forgiveness to his God, i.e. Bacchus, claiming that he is innocent of this condition, and that the God should blame love for it. He also reassures his fellows that such an event will not occur in the future, and that he will keep his vows to Bacchus forever.

Thirdly, Cappi and Diabelli, i.e. the publishers of Op. 102, may have liked the tempo marking Allegretto innocente employed by Giuliani, thus deciding to feature it in their own publication of the theme (supposedly utilised by Giuliani for his second transcription of 'Nume, perdonami' in Op. 120).

Finally, it is time to address the question of why Giuliani used a theme from Generali's 'Nume, perdonami' instead of Rossini's 'Arditi all'ire' in his Rossiniana No. 2. As previously introduced in this paper, one of Castelvecchi's speculations states that Giuliani may have done such a thing to allude to Rossini's plagiarism of Generali's aria. ${ }^{21}$ Castelvecchi backs up this suggestion by offering historical facts on both I Baccanali di Roma and Armida, as well as comparing the first measures of 'Nume, perdonami' from Cappi and Diabelli's vocal score (mentioned earlier) with the first measures of a non-specified vocal score of 'Arditi all'ire' - bearing the tempo marking Allegro brillante (1986, pp. 49-50). Castelvecchi states that the two themes are substantially the same, with the only difference being the types of modulation occurring in the second part of the themes in two-part song form at issue: while Generali's modulates from the tonic ( $\mathrm{D}$ major) to its dominant, Rossini's modulates from the tonic (F major) to its minor mediant (ibid., pp. 47-48). 
Table 1.

Ebuzio's lyrics in the cavatina 'Non temete: $i$ sommi Dei...Nume, perdonami'. (Generali, 1816, p. 10.)

\begin{tabular}{|c|c|}
\hline $\begin{array}{l}\text { 'Non temete: i sommi Dei... Nume, } \\
\text { perdonami' (Italian lyrics) }\end{array}$ & $\begin{array}{l}\text { 'Do not be afraid: the great Gods...God, } \\
\text { forgive me' (English translation) }\end{array}$ \\
\hline Ai Baccanti (coro): & To the Bacchants (choir): \\
\hline Non temete: i sommi Dei & Do not be afraid: the great Gods \\
\hline questo cor devoto adora & this heart devout[ly] adores. \\
\hline Il candor de' voti miei & The candor of my vows \\
\hline serberò costante ognor. & I will constant[ly] keep forever. \\
\hline A Bacco: & To Bacchus: \\
\hline Nume, perdonami & God, forgive me \\
\hline se in tale istante & if sometime[s] \\
\hline sfugge un sospiro & a sigh escapes \\
\hline ad un Baccante, & from a Bacchant, \\
\hline sospir che tenero & [a] sigh that tender \\
\hline parte dal cor... & leaves from the heart... \\
\hline Del mio deliro & Of my delirium[,] \\
\hline incolpa amor. & blame love. \\
\hline Ai Baccanti: & To the Bacchants: \\
\hline $\begin{array}{l}\text { Non temete: i voti miei } \\
\text { serberò costante ognor. }\end{array}$ & $\begin{array}{l}\text { Do not be afraid: my vows } \\
\text { I will constant[ly] keep forever. }\end{array}$ \\
\hline
\end{tabular}

However, by looking at Rossini's autograph of Armida it can be observed not only that 'Arditi all'ire' bears the tempo marking Allegro vivace (Figure 14), but above all that its theme's second part features a profoundly different melodic layout from 'Nume, perdonami' (Figure 15).

The above-mentioned two evidences reinforce the idea that after all Giuliani knew that the first part of Rossini's 'Arditi all'ire' was copied from Generali's cabaletta, and that for this reason he could insert Generali's theme (featuring a blatantly different second part) within the Rossiniana No. 2. Whether or not he did this because Rossini's cabaletta at issue was not among the originals which he borrowed from the Pesarese composer, or just out of a willingness to insert some sort of maliciously humorous 'comment' within Op. 120, or both, is something which might never be disclosed entirely. However, the above evidences 'insinuate' that Giuliani, a person who apparently had a sharp sense of humor, ${ }^{22}$ exercised such humor also in his music writing if the opportunity presented itself. ${ }^{23}$ 


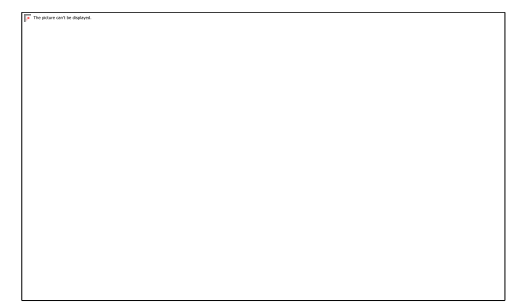

Figure 14. Tempo marking Allegro vivace (here spelled as All Viv) in the cabaletta 'Arditi all'ire', as featured in the autograph of Armida. (Rossini, 1817, p. 31r.)

Figure 15. Second part of Goffredo's melody in the theme of the cabaletta 'Arditi all'ire' from Armida. (Rossini, 1817, pp. 33r-34v.)

\section{Rossiniana No. 3: 'Sorte, secondami!' from Zelmira}

The upcoming hypothesis on the source for Giuliani's transcription of the theme of 'Sorte, secondami!' was born from a rather peculiar discovery made while examining Giuliani's autograph of the Rossiniana No. 3.

The cabaletta 'Sorte, secondami!' is featured in the introduction of Act 1, Scene 1, No. 1 of Rossini's opera Zelmira. Originally, its main theme is sung by the character Antenore (tenor), 'backed-up' by Leucippo (bass-baritone) and a Coro di guerrieri (Choir of warriors), and is contained within Antenore's cavatina 'Che vidi! Amici! Oh eccesso!...Sorte, secondami!': it is introduced after the tempo di mezzo 'In te il suo vindice' (sung by Leucippo and the choir) which separates the cavatina's cantabile (i.e. 'Che vidi! Amici! Oh eccesso!') from the cabaletta (Rossini, 1810-1840, pp. 16r-38v).

Giuliani's transcription of Antenore's theme in Op. 121 is rather authentic to the original material from the opera. However, Giuliani's autograph of Op. 121 shows that he wrote a preliminary version of the theme and variation on 'Sorte, secondami!' which was rather different from the version that apparently was chosen as the definitive one. ${ }^{24}$ 
Giuliani's preliminary version of the theme from Zelmira and its variation are found on pages 8 and 11 of his autograph manuscript (Figure 16, 17, and 18). They were crossed out by the composer, and later replaced with their definitive versions, found on pages 9 and 10 (Figure 19). Giuliani's replacement in the Rossiniana No. 3 seems to have happened after a change of opinion by him, which appears to have occurred when the score was pretty much ready to be published by Artaria, who issued the work in 1823 (Giuliani, 1823b; Heck, 2013, 'Works with opus number') and advertised it in the Wiener Zeitung on 12 January 1824 (Giuliani 2002, 'Preface: Publication'). In fact, Giuliani composed his definitive theme and variation on a new blank score sheet. The side of the sheet corresponding to the manuscript's page 10 only presents the final two measures of the definitive variation, therefore is almost completely empty of any music writing. This suggests that the page was inserted by the composer between pages 8 and 11 at the last moment.

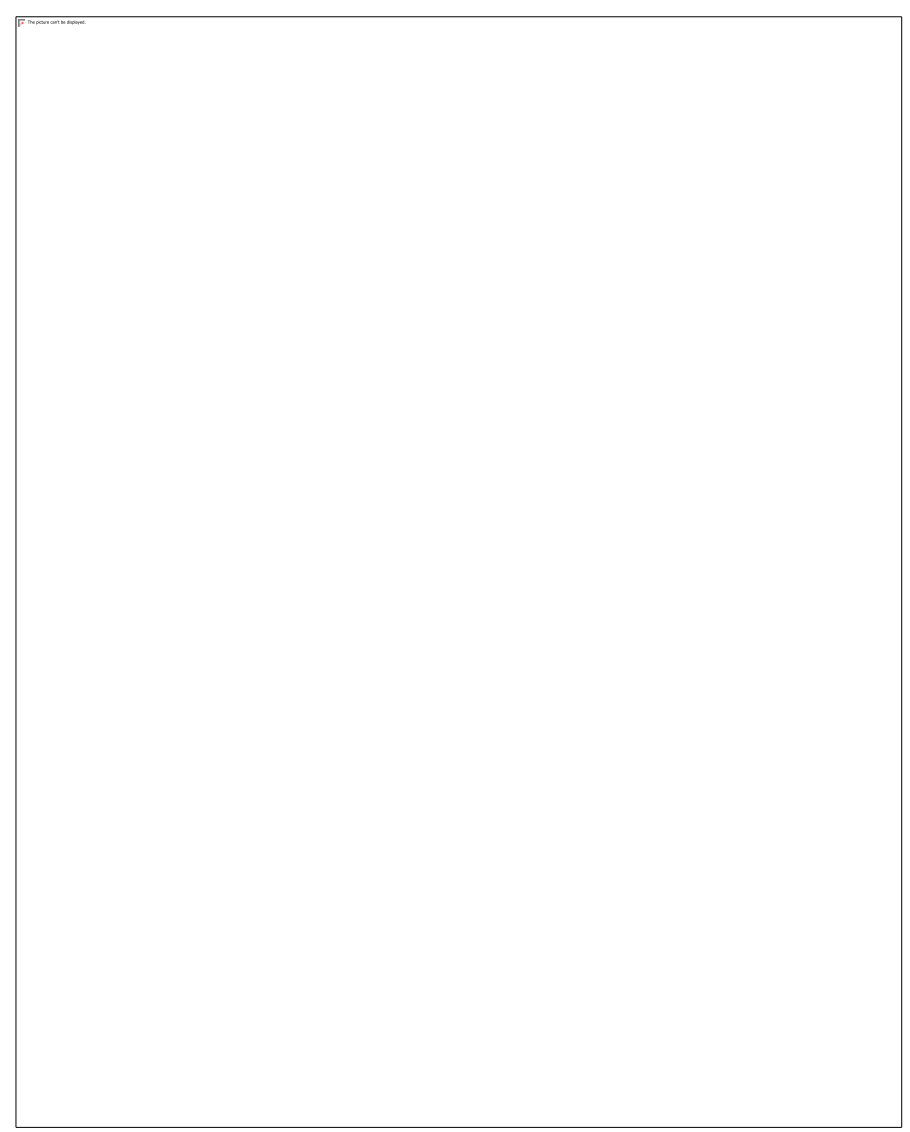

Figure 16. Rossiniana No. 3 (autograph): preliminary version of the theme of 'Sorte, secondami!' (blue border) and its variation (orange border). (Giuliani, ca. 1823, pp. 8 and 11.) 


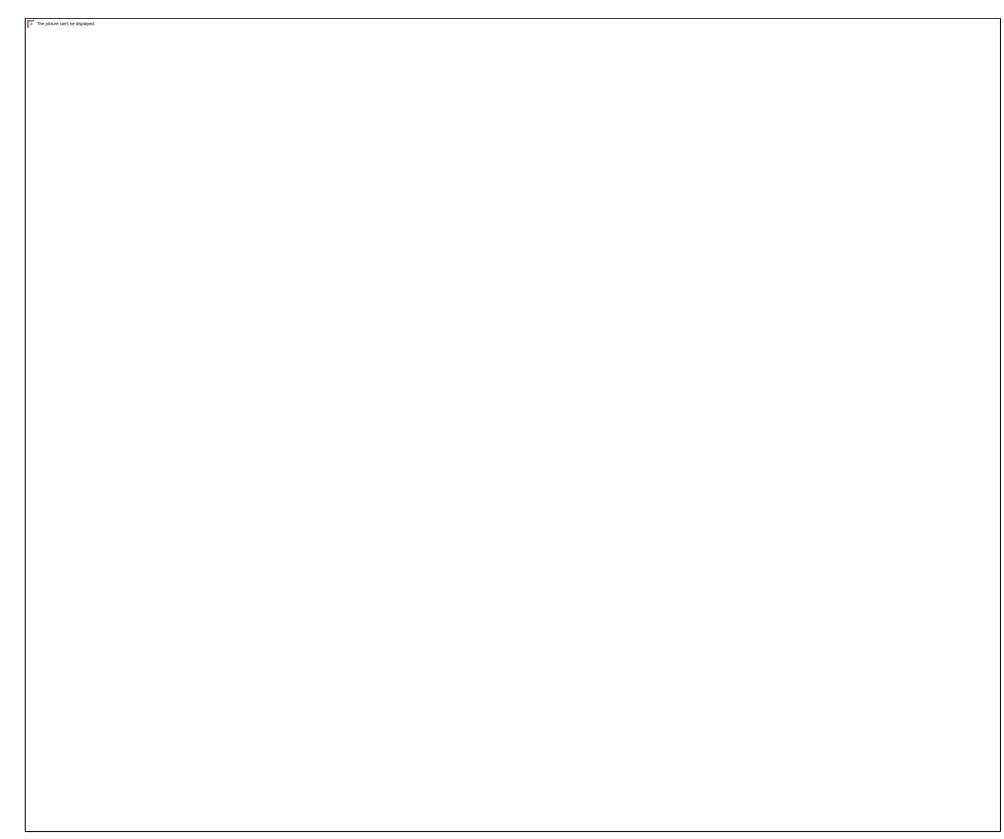

Figure 17. Reconstruction (by the author of this paper) of Giuliani's preliminary transcription of the theme of 'Sorte, secondami!'. (Giuliani, ca. 1823, pp. 8 and 11.)

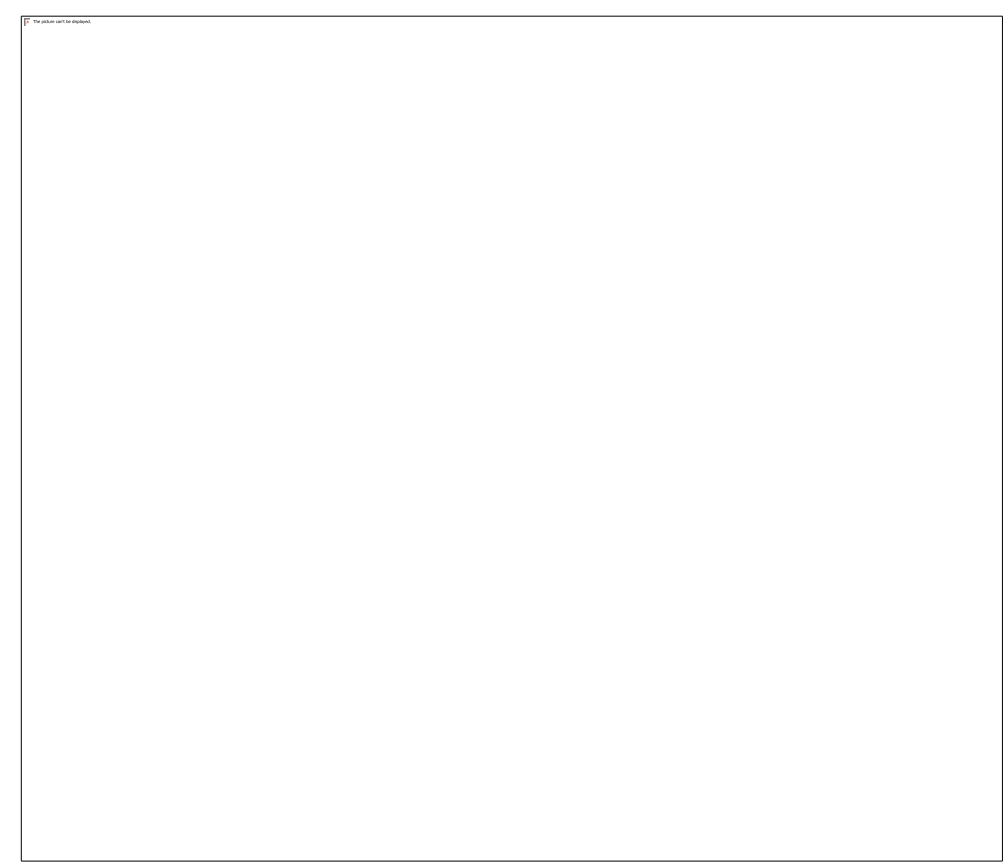

Figure 18. Reconstruction (by the author of this paper) of Giuliani's preliminary variation on his preliminary transcription of the theme of 'Sorte, secondami!'. (Giuliani, ca. 1823, p. 11.) 


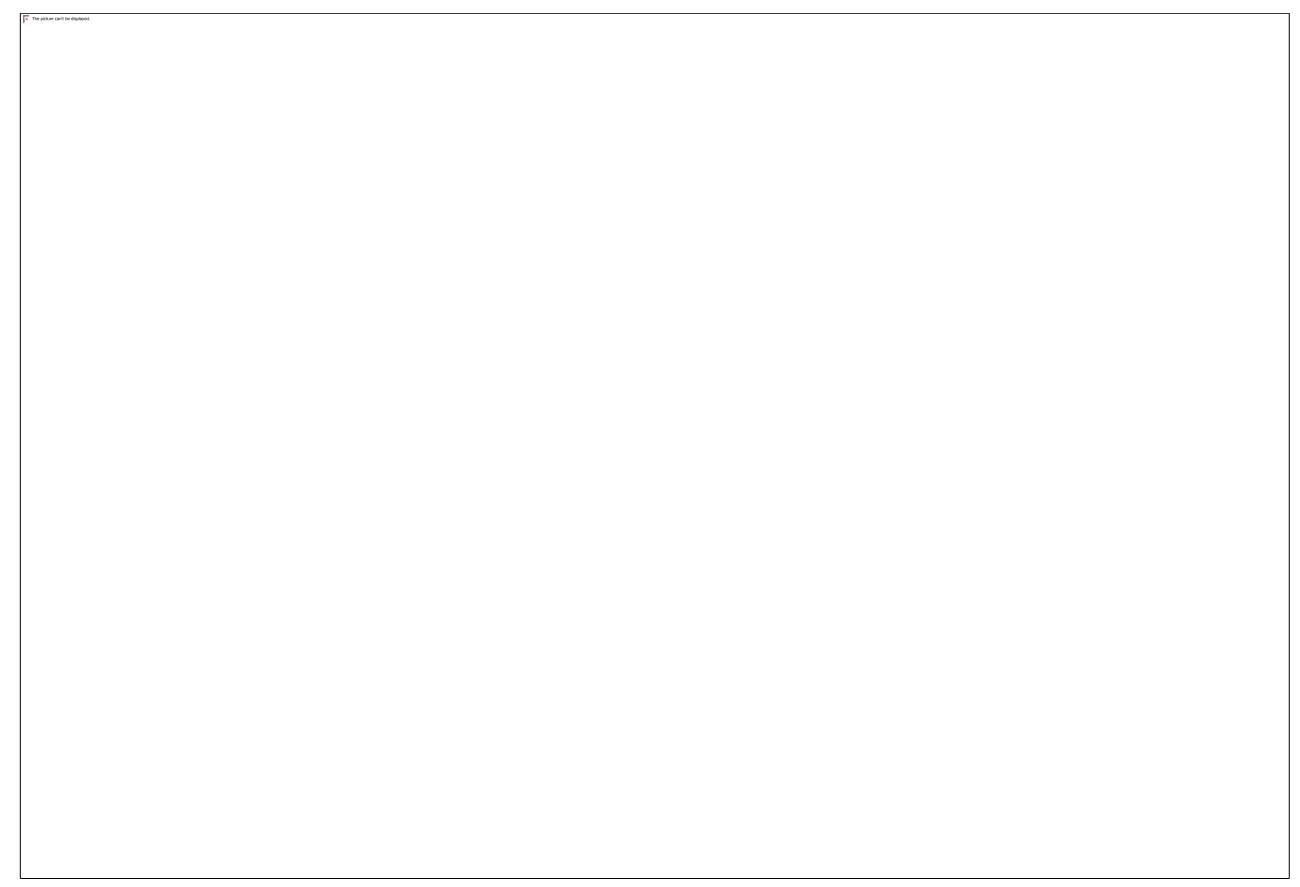

Figure 19. Rossiniana No. 3 (autograph): definitive transcription of both the theme of 'Sorte, secondami' and its variation. (Giuliani, ca. 1823, pp. 9-10.)

Among all the differences between Giuliani's preliminary and definitive version of 'Sorte, secondami!', both in the key of $\mathrm{G}$ major, the most striking one involves their respective harmonic progressions. More specifically, while in the preliminary version of the theme its repeated 8 measure long first part of the theme cadences on the submediant, in the definitive version the theme's 16 measure long first part cadences on the dominant (like in the original aria). However, why did Giuliani change his preliminary version of the theme with a version more accurate to the original aria?

Between March and July 1822, Rossini had a triumphant tour in Vienna. Accompanied by his manager Domenico Barbaia, his wife Isabella Colbran, and other six singers from the Teatro San Carlo of Naples, all together 'gave a total of 52 performances during their three-month stay' (Clark, 2005, pp. 137-138). During this tour Zelmira was particularly successful: the opera was performed a total of 21 times from its first Viennese performance on 13 April to its last one on 20 July (ibid., 140-145). Already highly praised at the time of its premiere at the Teatro San Carlo on 16 February 1822 (Rossini, 2005, p. xxv), Zelmira "created a furore both there and in Vienna" (Stendhal, 1957, p. 384), becoming so popular that the reviewer of the Allgemeine musikalische Zeitung of Leipzig decreed it as the season's triumph (Rossini, 2005, p. xxix). ${ }^{25}$

Due to Rossini's success in Vienna, the city's publishers engaged into a fierce competition with each other by overwhelming the market with an abundant number of transcriptions of his operas (ibid., xxxiii). In particular, it seems that the 
ones featuring themes from Zelmira garnered positive consensus in the city. As Benjamin Walton (2013) reports, at that time Zelmira's melodies "had been freely circulating since the opera's Viennese premiere back in April, arranged, varied, quadrilled, and potpourried [sic.]" (p. 159).

Zelmira's success led Artaria to publish approximately 20 among transcriptions and variations based on themes from this opera (Castelvecchi, 1986, p. 35), indeed an impressive number. However Artaria could do this rather easily, since Rossini provided him with the originals of Zelmira after an agreement reached during the composer's tour, so that the publisher could make a vocal score out of it (Rossini, 2005, pp. xxxiii-xxxiv). Such a score was published in 1822 (Rossini, 1822).

All this suggests that the replacement made by Giuliani could have been an idea of either him, or Artaria, or both. They may have believed that the transcription of the theme of 'Sorte, secondami!' should have sounded as similar as possible to the original one in order to be attractive to the Viennese audience, an audience that was rather familiar with the theme. Besides, it would make sense that Artaria wanted the transcription of material from Zelmira to sound as 'faithful' as possible, due to both the competition he was facing within the publishing business and, above all, the fact that he was the exclusive borrower of Zelmira's originals in Europe, something that possibly would have 'forced' him to publish transcriptions on themes from this opera which should not have sounded unauthentic once played.

This last assertion is fundamental when coming up with the hypothesis about the source for Giuliani's transcription of 'Sorte, secondami' for Op. 121: since in 1822 Artaria was the only publisher of a vocal score of Zelmira based on Rossini's originals, it is likely that Giuliani had this score as the source for his transcription, a score which could have been either provided to him by Artaria, or which he bought. This hypothesis seems to find confirmation in how Giuliani transcribed the accompaniment in his transcription: here he wrote dyads (Figure 20) 'inspired' by the ones found from the second to the fourth beat of every measure of the theme in Artaria's score (Figure 21), therefore mostly featuring inverted chords to be played in seventh position on the guitar. Giuliani may have decided to do this as he found out that, by transposing the original theme from $D$ to $G$ major, some of the dyads found in the accompaniment of the vocal score were adaptable on the guitar by following a similar technical pattern of inverted chords in seventh position that he had previously applied in his Sonata Op. 15 (Figure 22). More importantly, the orchestral score of Zelmira features a very characteristic march-like triplet rhythm in the second beat of every measure (Figure 23) - played by clarinets and horns which Artaria features only in the introduction of the aria (Figure 24). This implies that Giuliani may have transcribed the accompaniment of the theme according to Artaria's notational style for the sung part of the aria. 


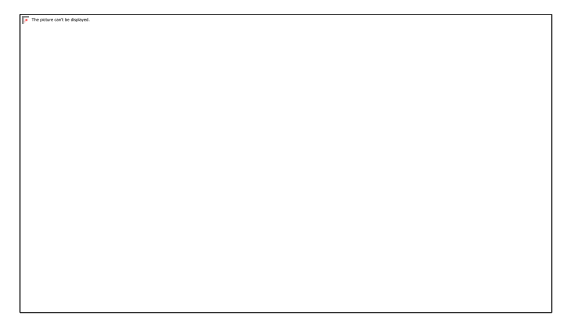

Figure 20. Rossiniana No. 3 (autograph): detail of the accompaniment in the definitive transcription of 'Sorte, secondami!' (bordered in red). (Giuliani ca. 1823, p. 9.)

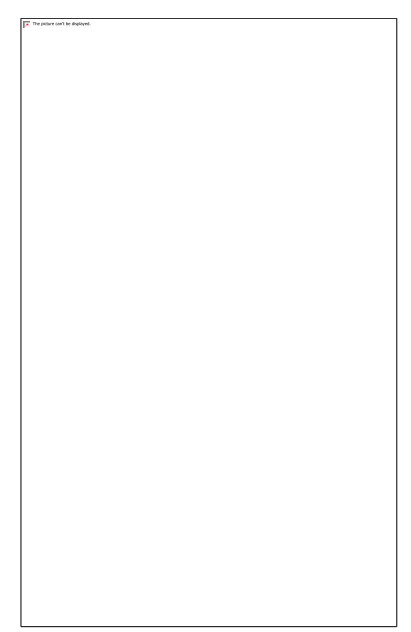

Figure 21. Detail of the piano accompaniment in 'Sorte, secondami!' (bordered in red), as featured in the vocal score published by Artaria. (Rossini, 1822, p. 14.)

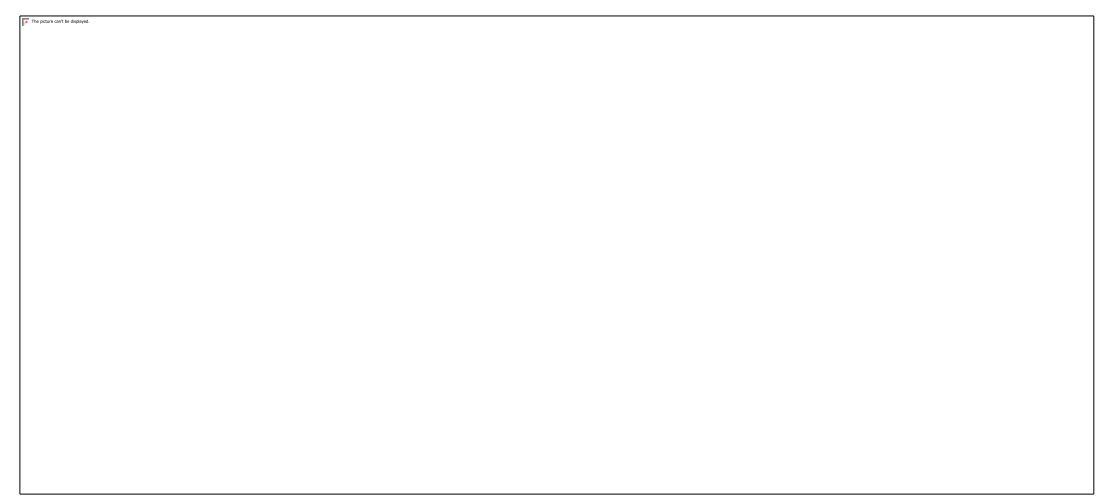

Figure 22. Detail of the accompaniment (bordered in red) featured in the 2nd movement of Giuliani's Sonata Op. 15. (Giuliani, s.a., p. 6) 


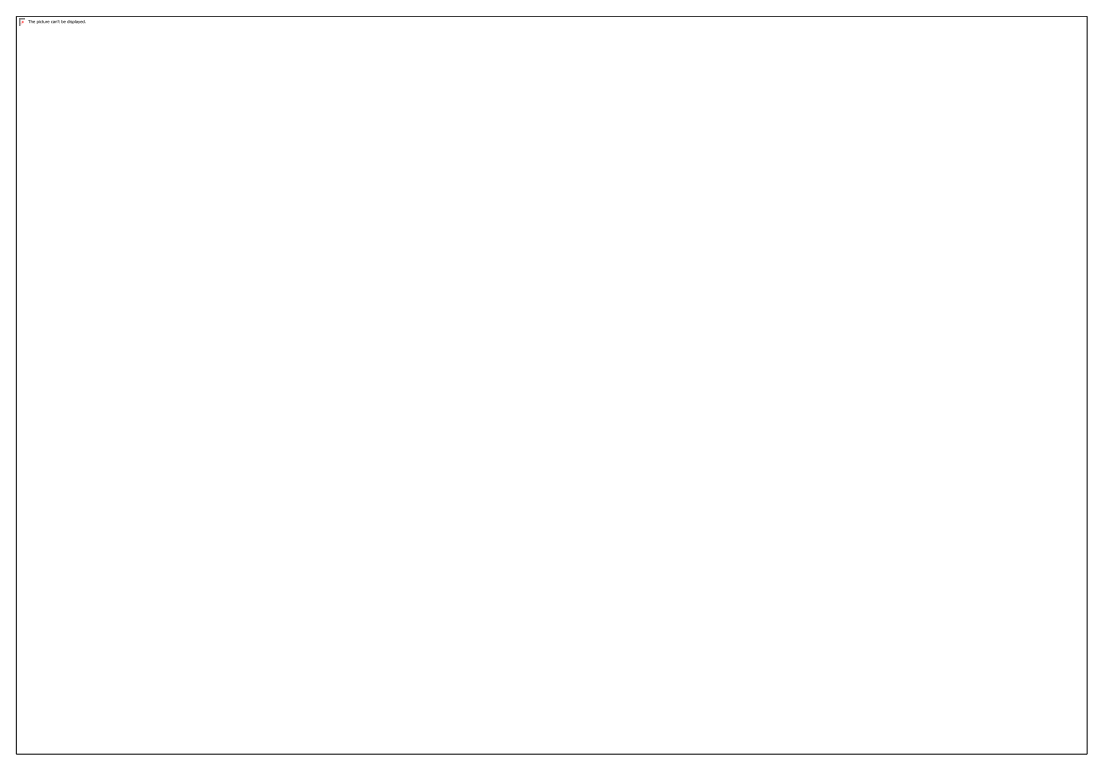

Figure 23. Zelmira (manuscript copy): detail of clarinets and horns' accompaniment (bordered in green) in 'Sorte secondami'. (Rossini, 1810-1840, p. 27.)

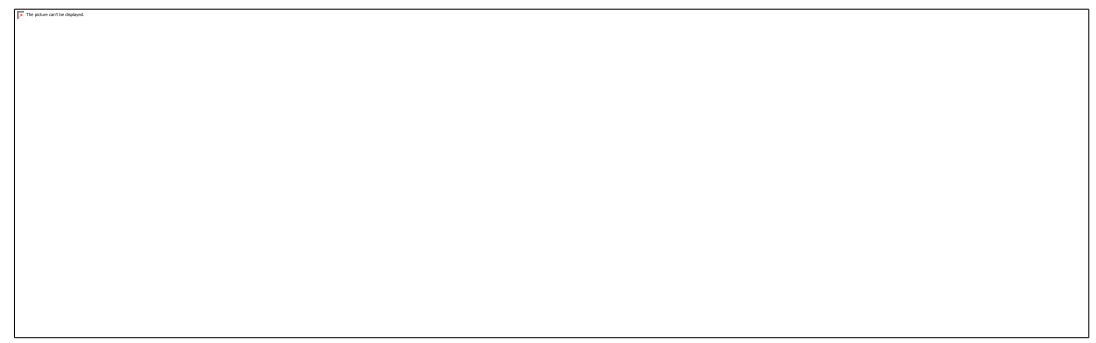

Figure 24. Detail of the triplet rhythm (bordered in green) in the second beat of every measure in the piano introduction of 'Sorte, secondami!', as featured in the vocal score published by Artaria. (Rossini, 1822, p. 14.)

Yet, the following evidence may render this hypothesis not valid. By comparing Giuliani's definitive theme in the autograph with Artaria's vocal score of Zelmira it can be immediately noticed that they reference the aria differently. In his vocal score Artaria titles the cabaletta as 'Aria (Sorte! secondami!) [sic.]' at the top of the page where Antenore's theme begins (Figure 25), and as 'Aria con Coro Sorte secondami [sic.; Aria with Choir Sorte secondami]' in the index of his publication (Figure 26). Instead, Giuliani wrongly references Antenore's theme as 'Quartetto dell' Opera Zelmira [sic.; Quartet from the Opera Zelmira] ${ }^{\prime 26}$ by utilizing a footnote (Figure 27). It is particularly interesting to note that Artaria and/or his editor(s) copy Giuliani's mistake in the first edition of Op. 121 (Figure 28), ${ }^{27}$ despite previously referencing Rossini's cabaletta as an aria in the vocal score. 


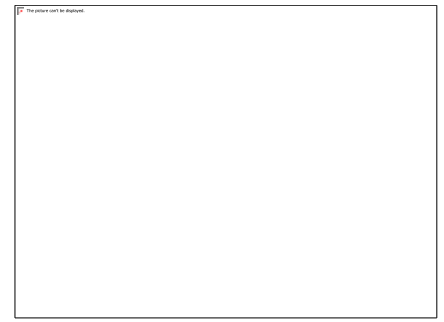

Figure 25. Title for the cabaletta 'Sorte, secondami!' (bordered in red) featured on the page of Artaria's vocal score where the cabaletta begins. (Rossini, 1822, p. 14.)

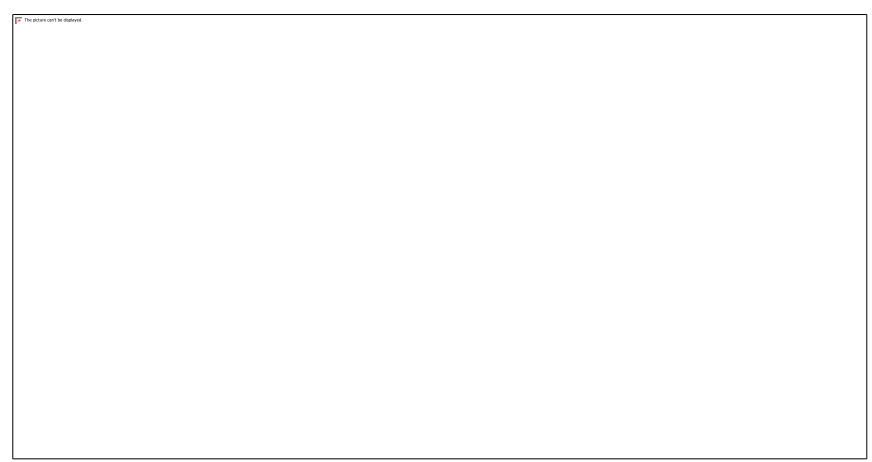

Figure 26. Title for the cabaletta 'Sorte, secondami!' (bordered in red) featured on the index of Artaria's vocal score. (Rossini, 1822, p. 14.)

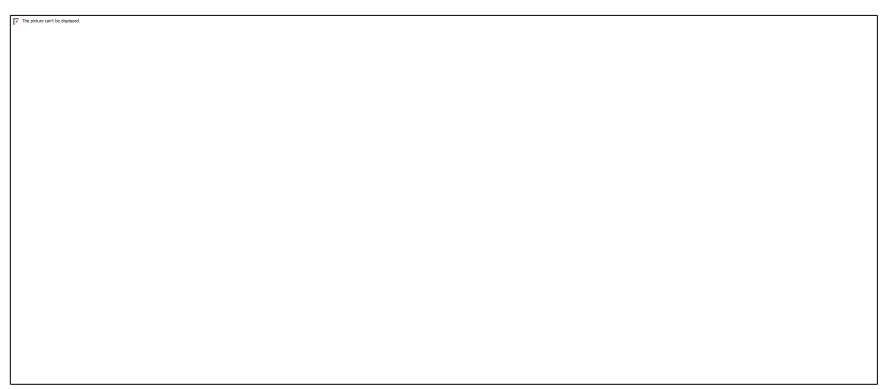

Figure 27. Footnote (green circles) referencing the theme from cabaletta 'Sorte, secondami!' featured in the autograph of Op. 121. Here score titles it as 'Quartetto dell'Opera Zelmira [sic.]'. (Giuliani, ca. 1823, p. 9.) 
Figure 28. Title for the theme of the cabaletta 'Sorte, secondami' (bordered in red) featured in Artaria's first edition of Op. 121. (Giuliani, 1823b, p. 9.)

This particular reference by Giuliani seems to be the sole element which feeds doubts about the source for his transcription. Nonetheless, from the reconstruction of the preliminary theme it can be seen that this features the letters within parentheses (c) both close-by the tempo marking and at the bottom of page 8 (Figure 29), a systematic modus operandi of Giuliani observable among the sole autographs of Le Rossiniane available to us which, besides Op. 121, includes Le Rossiniane No 5, Op. $123 .{ }^{28}$ The fact that the (c) at the bottom of page 8 does not report the reference of the aria from Zelmira instead retrievable from Giuliani's definitive transcription of the theme suggests that he wrote the references for all of his transcriptions right after writing all of the music in his work, instead of doing it while transcribing each theme. Therefore, the mistaken footnote in the definitive version of the theme may have happened as an inadvertence during the finishing stage of his composition - it can be speculated that this may have happened while in a rush to send his music to Artaria. If that is the case, the doubts presented previously about Giuliani's source for his theme from Zelmira may not subsist.

Figure 29. Rossiniana No. 3 (autograph): first fourteen measures of the preliminary transcription of the theme of 'Sorte, secondami!'. The page includes the letters within parentheses (c) (orange circles), designed to reference the theme. (Giuliani, ca. 1823, p. 8) 


\section{Conclusion}

Overall, this article offers many evidences on what were the sources that Giuliani employed for the themes of 'Nume, perdonami' and 'Sorte, scondami!' in Opp. 120 and 121 , i.e. the vocal score of Generali's cavatina of Ebuzio published by Cappi and Diabelli in 1820, and the vocal score of the opera Zelmira published by Artaria in 1822 respectively. Further, my research unveiled a possible source utilised by Giuliani to transcribe the theme for Op. 102, i.e. the vocal score of Die Bachanten published by Simrock between Easter 1818 and Easter 1819. Additionally, the comparisons between Generali and Rossini's original opera scores with their vocal score versions and Giuliani's transcriptions disclosed compelling clues about the Italian guitarist's potential reasoning behind some of his compositional choices for Opp. 102, 120, and 121 .

All the evidences presented in this article were obtained thanks to an indepth research of historical events regarding opera and music publishing. The results attained through this method of inquiry highlight how important it is to explore historical events of the nineteenth century in order to understand the culture behind the practice of music transcription of that era. At the same time, exploring nineteenth-century music transcriptions allows the rather curious scholars to bring to light interesting facts about history of opera and music publishing - e.g. my discovery of the actual date of I Baccanti di Roma's premiere in Venice and its review, as well as the reporting of the deal between Artaria and Rossini - thus demonstrating that, eventually, music transcription studies can be helpful in unveiling relevant issues regarding Western music history.

At last, the author of this study hopes to have made a small, helpful contribution to the field of music transcription, an art that was looked at only as a demonstration of bad musical taste for too long, and has only been legitimised recently. As Italian composer Alfredo Casella (1883-1947) strongly believed, the types of music transcriptions which can be considered artistically significant embody the materialisation of a musician's personal need to recreate through new sound(s) the feelings aroused in him/her by a particular original musical work, a procedure which involves his/her personality, taste, critical sense, and culture (1954, pp. 182-183). In this regard, the investigation within this article provides important data about Giuliani's compositional procedures as well as the underlying cultural and emotional impacts that the guitarist wished to deliver through them to both music readers and listeners of Le Rossiniane - e.g. the featuring of the tempo marking Allegretto innocente in Op. 120 to communicate the textual mood of Generali's original aria, and the featuring of a 'faithful' transcription of 'Sorte, secondami!' in Op. 121 to supposedly please the Viennese public - which, in my opinion, authenticate Giuliani's Le Rossiniane (or at least Opp. 120 and 121) as the types of transcriptions that Casella would have classified as works of art. 


\title{
Acknowledgements
}

I would like to address a special thanks to the following institutions for both their help and permission to publish their previously unpublished material (before this publication):

\author{
British Library, London \\ Ministero dei Beni e delle Attività Culturali e del Turismo - Biblioteca \\ Nazionale Marciana, Venice \\ Musiksammlung der Österreichische Nationalbibliothek, Vienna \\ Royal College of Music, London \\ Staatsbibliothek zu Berlin - Preußischer Kulturbesitz, Musikabteilung mit \\ Mendelssohn-Archiv
}

It is prohibited to reproduce the material in this article coming from the abovementioned libraries without their permission.

\section{Endnotes}

${ }^{1}$ In this paper I use the term transcription to signify both transcriptions and arrangements.

${ }^{2}$ As per Czerny, fantasia can be categorised into four species: 1) on a single theme; 2) on several themes; 3) "on so many subjects, that it should properly be called Pot-pourri [sic.]"; 4) capriccio.

${ }^{3}$ Rossini was in Rome for the premiere of his Matilde di Shabran, eventually conducted by Italian violinist and composer Niccolò Paganini (1782-1840) on 24 February 1821 (Osborne, 2002). Back in early December Rossini sent a letter to his mother, the singer Anna Guidarini (1771-1827), to inform her that he just arrived in the city (Rossini, 9 December 1820).

${ }^{4}$ This is documented in a letter sent by Giuliani to the publisher Giovanni Ricordi [17851853] on 6 February 1821. The English translation of Giuliani's original letter can be found in Heck, 2013, chap 4.2.2. (As a side note: for a concise summary of Mauro Giuliani's life and works see Heck, 2001.)

${ }^{5}$ One third of Giuliani's compositions consist of transcriptions; sixty of them are 'inspired' by operas (Riboni, 2011, p. 391).

${ }^{6}$ The previously-mentioned letter that Giuliani sent to Ricordi on February 1821 appears to be a good example of how Giuliani publicised his privilege of having received many originals from Rossini. It is safe to say that he probably gave this information to every publisher that later issued all of his Le Rossinane. The publishers at issue are Artaria - Opp. 119-121 - Diabelli - Opp. 122 and 123 - and Ricordi - Op. 124 (ibid., 'Works with opus number'.)

${ }^{7}$ As the reader will notice from the references provided at the end of the article, all scores which here I will attribute to both Cappi and Diabelli are referenced as 'Diabelli et Comp.'. This is not a mistake: the name of the publishing company reported in the scores at issue is the one reported on the references. However, I decided to attribute those scores also to Cappi in the main text due to the fact that, according to Weidmann and Warrack (2017), Cappi left the partnership with Diabelli in June 1824.

${ }^{8}$ A cabaletta (plural: cabalette) is "the second, usually fast movement of a double aria in an Italian opera, consisting of a melodic period of two stanzas which is repeated...after an orchestral ritornello" (Budden, 2001a). Due to the fact that within a cabaletta the two-stanza 
melodic period of the theme is repeated (more or less) in the same way as the first time, in this study each presented excerpt of a cabaletta theme coming from an (orchestral and vocal) opera score will come from the first presentation of the theme.

${ }^{9}$ In this paper I named this particular work by utilising the English translation by Heck (2013) of its original Italian title ('Works with opus number').

${ }^{10}$ This research gives me the opportunity to amend Galazzo's earlier report on the date of the premiere of I Baccanti di Roma which, according to his sources, took place at La Fenice on 14 January 1816 (Galazzo, 2009a, 79). According to my sources, the opera Zoraida (1815) by Giuseppe Farinelli (1769-1836) premiered in La Fenice as the first opera of the 18151816 Carnival season, and was performed until the first performance of Generali's (Girardi and Rossi, 1989, 80).

${ }^{11}$ All translations from Italian to English were made by the author of this paper. All of them were designed in order to give an as-literal-as-possible translation of both the words and the mood of Italian language.

${ }^{12}$ I also employed Galazzo's first volume to recover information not reported by the libretto about a) Binaghi's complete first name (reported by the libretto simply as 'Gio.'), and b) the name of the singer impersonating Lentulo and Augure Sommo, i.e. Giovanni Cengia (2009a, p. 79).

${ }^{13}$ In Italian operas of the first half of the nineteenth century, a cavatina was defined as an "extended aria for a lead singer at his or her first appearance on stage" (Balthazar, 2004, p. 51). As per Ochs (2001), a typical cavatina of this period was structured as a double-aria including a cantabile (slow) and a cabaletta (fast); these two arias were usually introduced by a recitative, and (often) separated from each other by a tempo di mezzo (pp. 61-62). The term tempo di mezzo is applied to "a[ny] fast transitional passage that separates a cantabile from a cabaletta ... It is generally free in form and varies in length according to the dramatic situation, its prime function being to effect the required change of mood" (Budden, 2001b). The term cavatina di sortita was often used in the nineteenth century as a more comprehensive term for the cavatina: it translates as 'exit cavatina', i.e. the cavatina that a main character would sing when exiting from the backstage for the first time in the opera.

${ }^{14}$ The question mark included in the reference's date is not a mistake. In fact, the Madrid score referenced here presents the wording 'ca. $1815^{\text {' }}$ on its first page. However, this is to be excluded since, as we already know, the premiere of Generali's opera happened in 1816. Therefore, in this article I will suppose that the score has been written in the second half of the $1810 \mathrm{~s}$, however further clarifications will be needed in the future. (With regard to this issue, unfortunately I received no reply from the National Library of Spain.)

${ }^{15}$ English translation: "However it is true that [M]ad[ame] Harles, whose qualities resonate in Monaco's theaters as well as others, and who here [in Venice] did not received scarce applauses [while performing] in the [just] ceased [o]pera of [M]r. Maestro Farinelli, found herself torn between the desire to preserve the fame that she enjoys - that is[,] of imprinting her [own] pleasant senses on the [a]udience - and the tiredness from the enormous fatigue to which she was subjected [by] incessant musical rehearsals multipl[ing] in the last days due to [a] delay [in the submission] of [the] music - among which the last one[, held on] the day before [the premiere, and] progress[ing] until two hours after midnight[, ended] in horrible [and] exhausting prostration - so much so that[, with] her zeal caught by sudden distress, [she] had to suddenly retreat at the end of her aria, in order to save the [a]udience [from assisting to] an emotional spectacle. Medical care rushed so soon, that it is hoped [that] she might recover as soon as possible, and that the [o]pera[, which] had to be suspended, may be brought to completion[, since] it is said that there are [still] interesting things in it [to be unveiled]. Such a restoration is indeed desirable; and[,] in the occurred mishap[,] the 
righteous [a]udience will recognise how much [the opera] is [both] eager [for] and worthy of their [positive] vote". What is reported here by the reviewer of I Baccanti di Roma seems to shed light on a specific fact about the date of its premiere. It is likely that the date found by Galazzo, i.e. 14 January 1816, was the initial date for the performance of Generali's opera. However, the reviewer affirms that there was a delay in the submission of the music, meaning that the opera had to be postponed to the actual date of its premiere, i.e. 14 February 1816.

${ }^{16}$ English translation: "From the music of Maestro Generali's first act were most applauded the cavatina di sortita [sung by M]r. Sebastiani, the duet between him and [M]ad[ame] Harles; and the other cavatina [sung by M]r. David".

17 As further confirmation, the Handbuch der musikalischen Litteratur (sic.) of 1821, reporting on the new publications available in German speaking and neighboring countries between Easter 1820 and Easter 1821 (Elvers and Hopkinson, 1972, p. 1), cites Cappi and Diabelli's publication among its list (p. 72). In addition, around the same period Cappi and Diabelli also issued a version for voice and guitar (ibid., p. 83). (Throughout this research I will be using all of the Handbuchs published between 1817 and 1821, yet I will only show data from three of them. Nonetheless, I will reference all of them at the end of the article together with their corresponding hyperlinks, so that the reader[s] can check my data.)

${ }^{18}$ Galazzo reports that the Viennese premiere was held in the same theater but on 25 March 1820 , and lists the one held on 12 June as the second performance (of probably the second series of performances) of the work in Vienna (2009b, p. 372). However, the Allgemeine musikalische Zeitung reports: "Theater an der Wien...Am 12. Jun[i] zum ersten Ma[1]e: [D]ie Bachanten, (richtiger Bacchanten) heroische Oper in Zwei aufzügen... Musik von P. Generali [Theater an der Wien ... On 12. June for the first time: Die Bachanten, (more properly Bacchanten [italic added]) heroic opera in two acts...music by P. Generali]". (Translation from German to English by the author of this paper.) According to Harrandt (personal communication, May 28, 2018), the 1820 score owned by the Austrian National Library "fits with the Viennese performance on $12^{\text {th }}$ [sic.] of June 1820 [at] the Theater an der Wien" (28 May 2018).

19 According to my examination of the second, third, fourth, and fifth editions of the Handbuch published between 1818 and 1821 - overall listing the published scores available in German speaking and neighboring countries from the end of 1815 to Easter 1821 (Elvers and Hopkinson, 1972, p. 1) - the score by Simrock was the only complete (vocal) score of Generali's opera available in the market featuring Generali's cavatina before Cappi and Diabelli's printed version of the aria.

${ }^{20}$ Readers of this paper may object that the melodic register of the second, third, and fourth measure in Figure 6 is much closer to the ones in Figure 10 and 12, rather than to those in Figure 13. However, it cannot be excluded that Giuliani may have transcribed the theme in Op. 102 by at the same time using the Simrock score and his transcribing ability while listening to performances. The latter viewpoint about his ability to transcribe by ear is based on a hypothesis of mine, hence here follow my evidences in support of it. Marco Riboni reports of a transcription made by Giuliani of a theme and two of its variations by French violinist Pierre Rode (1774-1830) which apparently is not consistent with Rode's original music (2011, pp. 402-403), i.e. the Air varié Op. 10 (1808) for violin and piano (Poriss, 2009 , p. 151). Instead, Giuliani's work is a transcription of another transcription by the Italian soprano Angelica Catalani (1780-1849), whose performance of it was reviewed by the Wiener Moden Zeitung on 4 July 1818 (Riboni, 2011, pp. 402-403). As a matter of fact, the final title that Giuliani gave to the entire opus in which such a transcription is included is Tre tema favoriti con variazioni di mdme Catalani messi per chitarra sola da Mauro 
Giuliani (Three favorite themes with variations by [Ma]d[a]me Catalani set on solo guitar by Mauro Giuliani; 1819), and the transcription of Rode's music is titled inside the publication as 'Sulle variazioni di Rode [On the variations of Rode]' (ibid.). However, it may also be likely that Giuliani made this transcription by ear while assisting to one (or more) of Catalani's performances, if not during the performance mentioned above. In fact, it appears that Catalani never published her transcription: as Hilary Poriss (2009) points out, there is only knowledge of "several surviving nineteenth-century piano-vocal [sic.] scores [which] contain ornaments attributed to Catalani, providing a sense of how she ... transformed [Rode's music] into a vocal work" (p. 152). According to my investigation of the first four editions of the Handbuch published between 1817 and 1820 - cataloguing the published scores available in German speaking and neighboring countries from ca. 1780 to Easter 1820 (Elvers and Hopkinson, 1972, p. 1) - there were only two versions for solo piano of Catalani's transcription which were issued by the publishing houses Steup (Amsterdam) and Christiani (Berlin) between Easter 1819 and Easter 1820 (Whistling, 1820, p. 29). Since Giuliani's transcription was advertised in the Wiener Zeitung on 9 January 1819 (Heck, 2013, 'Works without opus number'), the hypothesis that Giuliani transcribed Catalani's transcription by ear is not to be rejected. (The hypothesis about Giuliani's skills in transcribing by ear also points to the remote possibility that he may have transcribed the whole theme for Op. 102 without using a score. However, demonstrating this without any strong evidence would imply some risky conjecturing.)

${ }^{21}$ Since Rossini's lifetime it has been generally acknowledged that the composer used to plagiarise both his own and other composers' works. For instance, an article in The monthly magazine and literary journal titled 'The characteristics of Rossini's composition' (N/A, 1830) explores this issue within the Rossinian operatic repertoire rather thoroughly: "Our next object will be to consider a much more serious charge brought against [Rossini] by his adversaries, viz. that of being a plagiarist [sic.]. If the repetition and reproduction of an author's own ideas came under the denomination of plagiarism, Rossini must at once plead guilty; but, as the term is generally considered to apply exclusively to the appropriation of the thoughts or works of another [sic.], the question appears to be, how far Rossini has made free with the property of others. The question of plagiarism in music is too nice and uncertain in its limits to admit of a full enquiry in this place: it seems to be a question of degree. If the adoption of one [sic] bar of music, to be found in other works, constituted plagiarism, we know of no composer, not excepting Handel, Haydn, Mozart, or Beethoven, who could be exculpated from the charge; and, after all, it would remain to be ascertained who was the first that made use of the questionable bar. There is, we believe, an opinion current among the profession, that the appropriation of no less than four [sic.] bars constitutes actionable piracy. If so, Rossini has no cause to fear the arm of the law. We do not remember an instance of his introducing four bars, tali quali [sic.], from the works of a brother bard. But, if he be not amenable to the charge of legal piracy, there is such a thing as moral, constructive plagiarism, plagiarism in disguise. And in this respect Rossini, we fear, stand but an indifferent chance. He has largely borrowed in every quarter. Besides resorting to the national airs of Italy, he has, to a great extent, availed himself of the ideas of Generali [emphasis added] and Cimarosa, and other Italian authors; and the German composers, Haydn, Krommer, Mozart, \&c [sic.] have supplied materials for his scores. We have not room for a catalogue of these numerous Rossinian loans, the existence of many of which, we believe, is not disputed even by himself" (p. 59). It is likely that Rossini plagiarised parts from his as well as other composers' works due to his busy working schedule. As reported by American Rossini scholar Philip Gossett (1970), "[t]he factor most influential in Rossini's creative process was probably time ... Even while he held a steady positions [sic.] in Naples, 
from 1815 through 1822, Rossini continued to spend part of each year working for other theatres" (p. 50).

${ }^{22}$ Michael Lorenz (2015, April 28) reports of a particularly significant case in which Czech pianist and composer Joseph Gelinek (1758-1825) became the victim of Giuliani's merciless sarcasm during a Viennese musical gathering.

${ }^{23}$ An argument which may be brought up against the last paragraph's interpretation is that it would have been difficult for Giuliani to listen to Armida while residing in Rome between 1820 and 1823 (Heck, 2013, chap. 4.1-4.2.3), and therefore pick up the similarities between Generali and Rossini's themes. In fact Armida was not that successful in Italy: during Giuliani's lifetime, the whole opera was only performed in Naples (for five times) in November 1817 and in Venice in Autumn 1818 (Rossini, 1997, pp. xxxii-xxxiv), i.e. while Giuliani was still residing in Vienna. However, Armida enjoyed some fame in Germanspeaking countries (ibid., p. xxxii), starting from Vienna's premiere in December 1821 (ibid., xxxv). In light of this, it can be speculated that Giuliani may have known of Rossini's plagiarism via correspondence, probably informed by one (or more) of his Viennese contacts who attended the opera in the city; perhaps Artaria himself, i.e. the publisher of Op. 120, told Giuliani about this. It can be also speculated that Artaria could have been the person who suggested Giuliani to feature Generali's theme, due to the publisher's likely knowledge of the guitarist's previous publication of Op. 102. Therefore, the above would indicate that Giuliani's utilisation of Generali's theme in Op. 120 was more dictated by practicality rather than malice. However, if it is taken for granted that Giuliani did not assist to the actual performance of Armida, then what is not known is: a) if Giuliani was (made) aware that Rossini only plagiarised the first half of Generali's theme; b) if Giuliani ever cared not to 'offend' Rossini by (jokingly) featuring Generali's whole theme in the Rossiniana No. 2 given that he was informed about Rossini's partial plagiarism; c) whether Giuliani took the decision of employing Generali's theme all by himself, or by following a suggestion made either by Artaria, or by somebody else (from Vienna) conscious of the plagiarism. Since it is difficult to provide an answer to the above three points without venturing into an intricate series of highly objectionable speculations, the whole interpretation presented in the main text will be left as it is.

${ }^{24}$ Surprisingly, the only studies investigating Giuliani's autograph of the Rossiniana No. 3, that to my knowledge are available, do not report about this particular issue. The studies I am referring to are namely Brian Jeffery's preface for the thirteenth volume of Giuliani's Complete works in facsimiles - published by Tecla in 1986 (and reprinted in 2002) - and the rather recent paper by Marco Riboni titled 'Gli autografi di Mauro Giuliani' - published by Il Fronimo in April 2017. (Both the works cited here can be found among this article's references.)

${ }^{25}$ See also the enthusiastic letter that Rossini wrote to his mother on 15 April 1822 about the success of Zelmira's Viennese premiere (Rossini, 2005, pp. xxix), as well as the critical coverage of this opera by German-language newspapers (Clark, 2005, pp. 253-82).

${ }^{26}$ Giuliani's footnote can be translated in English in two ways: a) 'Quartet of the Opera Zelmira' (literal translation); 'Quartet from the Opera Zelmira' (correct English translation). This particular reference by Giuliani seems to be the sole element which can feed doubts about the fact Artaria's vocal score was the main source from which he derived his transcription.

${ }^{27}$ See respectively: a) Giuliani, ca. 1823 , and b) Giuliani, 1823 b.

${ }^{28}$ Giuliani always places either a letter (Op. 121) or a number (Op. 123) close-by the tempo marking above the theme that he wants to reference; he then reports the same letter or number at the bottom of the page and adds a note in order to notify the reader about the type 
of aria and its opera of provenance. (See respectively; a) Mauro Giuliani, ca. 1823, and b) Mauro Giuliani, 1823a)

\section{References}

Antolini, B. M. (2001). Nuove acquisizioni sull'editoria musicale in Italia (18001920). In Sirch, L. (Ed.), Canoni bibliografici. Contributi italiani al convegno internazionale IAML-IASA, Perugia, 1-6 settembre 1996 (pp. 95130). Lucca, Italy: Biblioteca Musicale LIM.

Balthazar, L. (2001). The forms of set pieces. In Balthazar, L. (Ed.), The Cambridge companion to Verdi (pp. 49-68). New York, NY: Cambridge University Press.

Budden, J. (2001a) Cabaletta. Grove music online. Retrieved from. https://doi.org/10.1093/gmo/9781561592630.article.04499.

Budden, J. (2001b) Tempo di mezzo. Grove music online. Retrieved from. https://doi.org/10.1093/gmo/9781561592630.article.O009496.

Casella, A. (1954). Il Pianoforte (3rd Ed.). Milano, Italy: Ricordi.

Castelvecchi, S. (1986). Le Rossiniane di Mauro Giuliani. Bollettino del centro rossiniano di studi, (1-3), pp. 34-68.

Clark, M. L. (2005). The performances and reception of Rossini's operas in Vienna, 1822-1825 (Doctoral dissertation). University of North Carolina.

Clive, P. (2001). Beethoven and his world: A bibliographical dictionary. New York, NY: Oxford University Press.

Czerny, C. (1848). School of practical composition, Vol. 1. London, United

Kingdom: R. Cocks \& Co. Retrieved from http://hdl.handle.net/1802/28412.

Elvers, R. \& Cecile H. (1972). A Survey of the music catalogues of Whistling and Hofmeister. Fontes Artis Musicae, 19 (1-2), 1-7. Retrieved from https://www.jstor.org/stable/23505205.

Galazzo, A. (2001a). Tra i Barbassori e gli Azzimati: Pietro Mercandetti Generali. Tomo I: La vita. Biella, Italy: Musica Antica a Magnano.

Galazzo, A. (2001b). Tra i Barbassori e gli Azzimati: Pietro Mercandetti Generali. Tomo II: Le opere. Biella, Italy: Musica Antica a Magnano.

Generali, P. (1816). I Baccanali di Roma, dramma serio del sig. Pietro Generali. Atto I (Ms.). Retrieved from the British Library, London, United Kingdom on 2017, February 1. Add. Ms. 31777.

Generali, P. (ca. 1818). Die Bachanten, Grosse Oper in 2 Aufzügen (1st Ed.). Bonn and Cologne, Germany: Simrock. Retrieved from the Library of the Royal College of Music, London, United Kingdom on 2018, July 2. Shelfmark: $\mathrm{H} 502$.

Generali, P. (181?). I Baccanali di Roma, musica del sig. M.ro Pietro Generali. Atto primo (Ms.). Retrieved from the digital archive of the Biblioteca Nacional de España, Madrid, Spain on 2017, January 8. bdhrd.bne.es/viewer.vm?id=0000169144\&page $=1$. 
Generali, P. (1820). Cavatina 'Nume perdonami/Götter ach verzeihet' aus der Oper: Baccanali di Roma, von Generali, mit Begleitung des Pianoforte. Philomele für Pianoforte, No. 41 (1st Ed.). Vienna, Austria: Diabelli et Comp.

Retrieved from the Musiksammlung der Österreichische Nationalbibliothek, Vienna, Austria on 2018, May 16. Shelfmark: Mus. Ms. 8469.

Generali, P. \& Rossi, G. (1816). I Baccanti di Roma, melo-dramma eroico in due atti da rappresentare nel Gran Teatro La Fenice nel carnevale 1816. Poesia, del sig. Gaetano Rossi. Musica, del sig. Pietro Generali. Venezia, Italy: Rizzi. Retrieved from the digital archive of the Library of Congress, Washington D.C., USA on 2019, March 17. https://www.loc.gov/resource/musschatz.13789.0/?sp=2.

Girardi, M. (2001). La musica nei periodici veneziani della seconda metà del Settecento e dell'Ottocento. In Sirch, L. (Ed.), Canoni bibliografici. Contributi italiani al convegno internazionale IAML-IASA, Perugia, 1-6 settembre 1996 (pp. 211-228). Lucca, Italy: Biblioteca Musicale LIM.

Girardi, M., \& Rossi, F. (1989). Il Teatro La Fenice: Cronologia degli spettacoli 1792-1936. Venezia, Italy: Albrizzi Editore.

Giuliani, M. (1819). Introduzione e variazioni sopra la cavatina favorita 'Nume perdonami, se in tale istante' nei Baccanali di Roma del sig. Generali, Op. 102 (1st Ed.). Vienna, Austria: Diabelli et Comp. Retrieved from the digital archive of the Rischel \& Birket-Smith Collection, Royal Danish Library, Copenhagen, Denmark on 2018, February 5. http://wayback01.kb.dk/wayback/20101028104955/http://www2.kb.dk/elib/noder/rischel/ RiBS0346.pdf.

Giuliani, M. (1822). Le Rossiniane per la chitarra seconda parte, Op. 120 (1st Ed.). Vienna, Austria: Artaria e Compag. Retrieved from the digital archive of the Rischel \& Birket-Smith Collection, Royal Danish Library, Copenhagen, Denmark on 2017, April 20. http://wayback01.kb.dk/wayback/20101028105025/http://www2.kb.dk/elib/noder/rischel/ RiBS0359-2.pdf.

Giuliani, M. (ca. 1823). Le Rossiniane per chitarra parte terza, Op. 121 (AMs.). Retrieved from the Preußischer Kulturbesitz, Musikabteilung mit Mendelssohn-Archiv. Staatsbibliothek zu Berlin, Berlin, Germany on 2016, January 26. Mus. Shelfmark: Ms. 7600/1.

Giuliani, M. (1823a). Le Rossiniane per chitarra, o lira, Op. 123 (AMs.). Retrieved from the Musiksammlung der Österreichische Nationalbibliothek, Vienna, Austria on 2016, February 4. Shelfmark: Mus. Hs. 35842.

Giuliani, M. (1823b). Le Rossiniane per la chitarra terza parte, Op. 121 (1st Ed.). Vienna, Austria: Artaria e Compag. Retrieved from the digital archive of the Rischel \& Birket-Smith Collection, Royal Danish Library, Copenhagen, Denmark on 2017, April 20. http://wayback01.kb.dk/wayback/20101028105027/http://www2.kb.dk/elib/noder/rischel/ RiBS0359-3.pdf.

Giuliani, M. (s.a.). Sonate brillant für die Guitarre, 15tes Werk (2nd Ed.). Vienna, Austria: Steiner und Comp. Retrieved from the digital archive of the Rischel 
\& Birket-Smith Collection, Royal Danish Library, Copenhagen, Denmark on 2018, April 14. http://wayback-

01.kb.dk/wayback/20101028104637/http://www2.kb.dk/elib/noder/rischel/ RiBS0272.pdf.

Giuliani, M. (2002). The complete works in facsimiles, Vol. 13 (B. Jeffery, Ed.).

London, United Kingdom: Tecla Editions.

Gossett, P. (1970). Gioachino Rossini and the conventions of composition. Acta

Musicologica, 42 (1-2), 48-58. Retrieved from

https://www.jstor.org/stable/932268.

Heck, T. F. (2001). Mauro Giuliani. Grove music online. Accessed on 2018, May

14. https://doi.org/10.1093/gmo/9781561592630.article.11230.

Heck, T. F. (2013). Mauro Giuliani: A life for the guitar (Kindle Ed.). Austin, TX:

Guitar Foundation of America.

Lorenz, Michael. (2015, April 28). A Giuliani anecdote. Retrieved from http://michaelorenz.blogspot.com/2015/04/a-giuliani-anecdote.html.

Miller-Kay, E. (2018). Four-hand piano transcriptions and the reception of symphonic repertoire in nineteenth-century Europe. Malaysian Journal of Music, 7, 195-207.

N/A. (1816, February 14). Il Nuovo Postiglione, No. 26. Retrieved from the Biblioteca Nazionale Marciana, Venice, Italy on 2016, February 9. Shelfmark: PER. 0001035.1816.

N/A. (1816, February 16). Il Nuovo Postiglione, No. 27. Retrieved from the Biblioteca Nazionale Marciana, Venice, Italy on February 9, 2016. Shelfmark: PER. 0001035.1816.

N/A. (1820, June 17). Allgemeine musikalische Zeitung, No. 49. Retrieved from

'ANNO: AustriaN Newspapers Online', Österreichische Nationalbibliothek, Vienna, Austria on 2018, May 7. http://anno.onb.ac.at/cgi-content/annoplus?aid $=$ amz \&datum $=1820 \&$ page $=207 \&$ size $=45 \&$ qid $=$ NWQ4JCO7W3U VUWWDZO75BKPPDRV4GJ.

N/A. (1820, June 29). Wiener allgemeine Theaterzeitung und Unterhaltungsblatt, No. 78. Retrieved from 'ANNO: AustriaN Newspapers Online', Österreichische Nationalbibliothek, Vienna, Austria on 2018, May 7. http://anno.onb.ac.at/cgicontent/anno?aid $=$ thz\&datum $=18200629 \&$ seite $=3 \&$ zoom $=33 \&$ query $=022$ wiener $\% 22 \% 2 \mathrm{~B} \% 22$ zeitung\%22\%2B\%22generali\%22\%2B\%221820\%22\& ref=anno-search.

N/A. (1830). The characteristics of Rossini's compositions. The new monthly magazine and literary journal, 28 (1), 55-62. Accessed on 2019, June 1. https://books.google.com.hk/books?id=9yxKAAAAMAAJ\&printsec $=$ frontc over $\# \mathrm{v}=$ onepage $\& \mathrm{q} \& \mathrm{f}=$ false.

Ochs, A. A. (2001). Opera in contention: Social conflict in late nineteenth-century Mexico City (Doctoral dissertation: University of North Carolina).

Osborne, R. (2002). Matilde di Shabran. Grove music online. Accessed on 2019, March 24. Retrieved from https://doi.org/10.1093/gmo/9781561592630.article.O007599. 
Poriss, H. (2009). Changing the score: arias, prima donnas, and the authority of performance. New York, NY: Oxford University Press.

Riboni, M. (2011). Mauro Giuliani. Palermo, Italy: L'Epos.

Riboni, M. (2017). Gli autografi di Mauro Giuliani. Il Fronimo, 178 (2), pp. 7-21.

Rossini, G. (1810-1840). Zelmira: Melodramma in due atti di Andrea Leone Tottola. Musica del sig. Gioacchino Rossini. Atto primo (Ms.). Retrieved from Internet Culturale: Biblioteca del Conservatorio San Pietro a Majella, Naples, Italy on 2019, March 21.

http://www.internetculturale.it/jmms/iccuviewer/iccu.jsp?id=oai\%3Awww.i nternetculturale.sbn.it $\% 2$ FTeca $\% 3 \mathrm{~A} 20 \% 3 \mathrm{ANT} 0000 \% 3 \mathrm{AIT} \% 5 \mathrm{C} \% 5 \mathrm{CICCU}$ $\% 5 \mathrm{C} \% 5 \mathrm{CMSM} \% 5 \mathrm{C} \% 5 \mathrm{C} 0166029 \&$ mode=all\&teca=MagTeca+-+ICCU.

Rossini, G. (1817). Armida. (AMs.). Retrieved from Internet Culturale: Biblioteca della Fondazione Rossini, Pesaro, Italy on 2019, March 21.

http://www.internetculturale.it/jmms/iccuviewer/iccu.jsp?id=oai\%3Awww.i nternetculturale.sbn.it $\% 2$ FTeca $\% 3 \mathrm{~A} 20 \% 3 \mathrm{ANT} 0000 \% 3 \mathrm{AIT} \% 5 \mathrm{C} \% 5 \mathrm{CICCU}$ $\% 5 \mathrm{C} \% 5 \mathrm{CURB} \% 5 \mathrm{C} \% 5 \mathrm{C} 0665466 \&$ mode $=$ all\&teca $=$ MagTeca+-+ICCU.

Rossini, G. (1820, December 9). Lettere manoscritte di Gioachino Rossini: Guidarini, Anna. Retrieved from Internet Culturale: Fondazione Rossini, Pesaro, Italy on 2019, March 24.

http://www.internetculturale.it/jmms/iccuviewer/iccu.jsp?id=oai\%3Awww.i nternetculturale.sbn.it\%2FTeca\%3A20\%3ANT0000\%3APU_LEG1i0AFR1 0152\&mode $=$ all\&teca=MagTeca+-+ICCU.

Rossini, G. (1822). Zelmira: Opera seria messa in musica dal sig. Maestro Rossini, ridotta per pianoforte dal sig. Maestro Girowetz (1st Ed.). Vienna, Austria: Artaria e Comp. Retrieved from Internet Culturale: Biblioteca della Fondazione Rossini, Pesaro, Italy on 2018, March 6.

http://www.internetculturale.it/jmms/iccuviewer/iccu.jsp?id=oai\%3Awww.i nternetculturale.sbn.it\%2FTeca\%3A20\%3ANT0000\%3AMUS0267536\&m ode=all\&teca $=$ MagTeca+-+ICCU.

Rossini, G. (1997). Armida: Partitura atto primo (C. S. Brauner \& P. B. Brauner, Eds.). Pesaro, Italy: Fondazione Rossini.

Rossini, G. (2005) Zelmira: Partitura atto primo (H. Greenwald \& K. Kuzmik Hansell, Eds.). Pesaro, Italy: Fondazione Rossini.

Samson, J. (2001). The great composer. In J. Samson (Ed.), The Cambridge history of nineteenth-century music, Vol. 1 (pp. 259-284). Cambridge, United Kingdom: Cambridge University Press.

Stendhal. (1957). Life of Rossini (R. N. Coe, Trans.). New York, NY: Criterion Books.

Urrows, D. F. (2008). Conscientious translation: Liszt, Robert Franz, and the phenomenology of Lied transcription. In D.F. Urrows. (Ed.), Word \& music studies, Vol. 9: Essays on word/music adaptation and on surveying the field (pp. 135-160). Amsterdam, Netherlands: Rodopi.

Walton, B. (2013). More German than Beethoven: Rossini's Zelmira and Italian style. In N. Matthew \& B. Walton (Eds.), The invention of Beethoven and 
Rossini: Historiography, analysis, criticism (pp. 159-177). Cambridge, United Kingdom: Cambridge University Press.

Weinmann, A. (1983). Beiträge zur Geschichte des Alt-Wiener Musikverlages, Reihe 2, Folge 23, Veralgsverzeichnis Peter Cappi und Cappi \& Diabelli (1816 bis 1824). Vienna, Austria: Musikverlag Ludwig Krenn.

Weidmann, A. \& Warrack, J. (2001). Diabelli, Anton. Grove music online.

Accessed on 2017, November 14. Retrieved from

https://doi.org/10.1093/gmo/9781561592630.article.07710.

Whistling, C. F. (1817). Handbuch der musikalischen Litteratur. Leipzig, Germany:

Meysel. Retrieved from the digital archive of the Bayerische

Staatsbibliothek, Munich, Germany on 2019, March 17. http://mdz-nbnresolving.de/urn:nbn:de:bvb:12-bsb10598698-4.

Whistling, C. F. (1818). Handbuch der musikalischen Litteratur. Erster Nachtrag.

Leipzig, Germany: Meysel. Retrieved from the digital archive of the

Bayerische Staatsbibliothek, Munich, Germany on 2019, March 17.

http://mdz-nbn-resolving.de/urn:nbn:de:bvb:12-bsb10598699-4.

Whistling, C. F. (1819). Handbuch der musikalischen Litteratur. Zweiter Nachtrag.

Leipzig, Germany: Hofmeister. Retrieved from the digital archive of the

Bayerische Staatsbibliothek, Munich, Germany on 2019, March 17.

http://mdz-nbn-resolving.de/urn:nbn:de:bvb:12-bsb10598700-2.

Whistling, C. F. (1820). Handbuch der musikalischen Litteratur. Dritter Nachtrag.

Leipzig, Germany: Hofmeister. Retrieved from the digital archive of the

Bayerische Staatsbibliothek, Munich, Germany on 2019, March 17.

http://mdz-nbn-resolving.de/urn:nbn:de:bvb:12-bsb10598701-8.

Whistling, C. F. (1821). Handbuch der musikalischen Litteratur. Vierter Nachtrag.

Leipzig, Germany: Hofmeister. Retrieved from the digital archive of the

Bayerische Staatsbibliothek, Munich, Germany on 2019, March 17.

http://mdz-nbn-resolving.de/urn:nbn:de:bvb:12-bsb10598702-3.

\section{Biography}

Francesco Teopini Terzetti Casagrande is a professional classical guitarist, teacher, and musicologist currently living in Hong Kong. After graduating in guitar performance from the conservatory ' $G$. B. Martini' in Bologna, he went to further study at the Royal Academy of Music in London, where he was awarded the Postgraduate Diploma in Guitar Performance (Distinction). His first international release with Brilliant Classics, J. S. Bach: Sonatas and partitas BWV 1001-1006 (2016), has been receiving enthusiastic praises from audiences and critics alike: "Teopini depicts these extraordinary works in a warm, human, relaxed and stylish manner" (Musikalifeten, Netherlands); "[an] intense and felt interpretation...[with a sound] endowed with warmth and attack but also power" (Diapason, France); "a recording that achieves a beautiful sound and a dignified interpretation" (Melómano Digital, Spain). Currently, Teopini is a $\mathrm{PhD}$ candidate in musicology at the Hong Kong Baptist University under the prestigious Hong Kong PhD Fellowship Scheme. 